\title{
Temporal variability of live (stained) benthic foraminiferal faunas in a river-dominated shelf - Faunal response to rapid changes of the river influence (Rhône prodelta, NW Mediterranean)
}

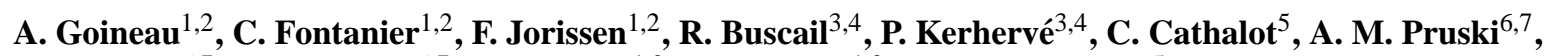 \\ F. Lantoine ${ }^{6,7}$, S. Bourgeois ${ }^{6,7}$, E. Metzger ${ }^{1,2}$, E. Legrand ${ }^{1,2}$, and C. Rabouille ${ }^{5}$ \\ ${ }^{1}$ Laboratoire d'Etude des Bio-Indicateurs Actuels et Fossiles (BIAF), UMR 6112 CNRS, LPGN-BIAF, France \\ ${ }^{2}$ Laboratoire d'Etude des Bio-Indicateurs Marins (LEBIM), Ker Châlon, 85350 Ile d'Yeu, France \\ ${ }^{3}$ Univ. Perpignan Via Domitia, CEntre de Formation et de Recherche sur les Environnements Méditerranéens, UMR 5110, \\ 66860, Perpignan, France \\ ${ }^{4}$ CNRS, CEntre de Formation et de Recherche sur les Environnements Méditerranens, UMR 5110, 66860, Perpignan, France \\ ${ }^{5}$ Laboratoire des Sciences du Climat et de l'Environnement (LSCE), UMR 1572 CEA-CNRS-UVSQ, \\ 91198 Gif-sur-Yvette Cedex, France \\ ${ }^{6}$ UPMC Univ Paris 06, FRE 3350, Laboratoire d'Ecogéochimie des Environnements Benthiques (LECOB), \\ Observatoire Océanologique, 66650, Banyuls-sur-Mer, France \\ ${ }^{7}$ CNRS, FRE 3350, LECOB, Observatoire Océanologique, 66650, Banyuls-sur-Mer, France
}

Correspondence to: A. Goineau (a.goineau@gmail.com)

Received: 22 June 2011 - Published in Biogeosciences Discuss.: 6 September 2011

Revised: 28 January 2012 - Accepted: 13 February 2012 - Published: 13 April 2012

\begin{abstract}
In the context of the French research project CHACCRA (Climate and Human-induced Alterations in Carbon Cycling at the River-seA connection), living (rose Bengal-stained) benthic foraminifera were investigated at two stations (24 and $67 \mathrm{~m}$ depth) in the Rhône prodelta (NW Mediterranean, Gulf of Lions). The aim of this study was to precise the response of benthic foraminiferal faunas to temporal changes of the Rhône River inputs (e.g. organic and terrigeneous material). Each site was sampled in April 2007, September 2007, May 2008 and December 2008, permitting to observe foraminiferal faunas of the 63-150 and $>150 \mu \mathrm{m}$ size fractions under a wide range of environmental conditions. Obvious variations in foraminiferal faunal composition were observed during the four investigated periods at the shallowest Station A located in the close vicinity of the Rhône River mouth. After major Rhône River flood events, different colonisation stages were observed with foraminiferal faunas responding with an opportunistic strategy few days to weeks after the creation of a peculiar sedimentary environment (Leptohalysis scottii, May 2008) or high organic matter supplies (Ammonia tepida, December 2008). Under more stable conditions, relatively diverse and equilibrated faunas grew in the sediments. Species benefited from noticeable input of riverine phytodetritus to the sedi-
\end{abstract}

ment during spring bloom conditions (April 2007; e.g. Bolivina dilatata, Nonionella stella, Stainforthia fusiformis), or high amounts of still bio-available organic matter under more oligotrophic conditions (September 2007; e.g. Ammonia tepida, Psammosphaera fusca). The reduced influence of the Rhône River input at the farther Station N led to less contrasted environmental conditions during the four sampling periods, and so to less obvious variations in foraminiferal faunal composition. During reduced riverine influence (i.e. low Rhône discharge), species able to feed on fresh phytodetritus (e.g. Clavulina cylindrica, Hopkinsina atlantica, Nonionella iridea and Nonionella turgida) benefited from eutrophic conditions of the spring bloom (April 2007, May 2008). Conversely, the occurrence of Nouria polymorphinoides under oligotrophic conditions (September 2007, December 2008) was indicative of a benthic environment potentially disturbed by bottom currents. This study put into evidence the extremely rapid response of benthic foraminiferal faunas to strong variations in environmental conditions mostly induced by the Rhône dynamics. 


\section{Introduction}

River-dominated shelves constitute dynamic environments at the interface between the continent and the ocean. In these areas, dissolved nutrients supplied by the river induce a local increase in primary production and fresh organic matter export to the sea floor (Lohrenz et al., 1990, 1997; Dagg and Breed, 2003). Moreover, the high variability over time of riverine discharge leads to contrasted environmental conditions in the coastal ocean. In the Rhône River prodelta, important sediment inputs (continental organic and inorganic material) related to flood events change the benthic environment by disturbation from steady state conditions diagenetic processes (Cathalot et al., 2010; Pastor et al., 2011) and macrofaunal activity (Salen-Picard et al., 2002; Hermand et al., 2008). In such a dynamic environment, benthic foraminiferal faunas may also vary significantly in space and in time. Benthic foraminiferal assemblages have previously been analysed at a kilometer-scale in the Rhône prodelta (15 to $100 \mathrm{~m}$ depth, 1 to $22.4 \mathrm{~km}$ off the mouth) during two sampling seasons (Mojtahid et al., 2009; Goineau et al., 2011). Both studies permitted to get snapshots of foraminiferal faunas at the scale of the prodelta under two contrasted environmental conditions, eutrophic (i.e. late spring bloom, June 2005) and oligotrophic (i.e. late summer, September 2006) settings. Despite different conditions, foraminiferal communities show similar bio-zonation depending on hydro-sedimentary processes and on the quality/quantity of sedimentary organic matter. Nevertheless, some differences appear when comparing relative abundances of major species. Indeed, a strong contribution of the most opportunistic species (e.g. Bulimina aculeata, Cassidulina carinata, Valvulineria bradyana) is noticed in June 2005. It might be related to a response to fresh phytodetritus input related to spring bloom conditions. Unfortunately, the different locations of the study stations during both sampling periods and the lack of key environmental parameters such as chlorophyll- $a$ content within the sediment precluded reliable and relevant interpretations concerning the temporal variability of foraminiferal communities in the Rhône prodelta. A temporal survey of both small- $(63-150 \mu \mathrm{m})$ and large-sized foraminiferal faunas $(>150 \mu \mathrm{m})$ supported by a complete characterisation of biotopes would allow us to determine the impact of changing environmental conditions (e.g. hydro-sedimentary processes, quality/quantity of the organic matter) on the foraminiferal faunas in the Rhône prodelta. Furthermore, the dynamics of foraminiferal assemblages and associated time scales for ecosystem adaptation is needed to relate abrupt changes of river delivery (floods) to ecosystems dynamics. Such a study has never been done until now.

In this paper, we investigate the temporal variability of live (stained) benthic foraminiferal faunas from the Rhône prodelta at two sites sampled during four periods with contrasted environmental conditions. Sites A and N (24 and $67 \mathrm{~m}$ depth, respectively) were both visited in April 2007, September 2007, May 2008 and December 2008, these sampling dates cover a wide range of environmental conditions from low to high discharge (flood), and from oligotrophic to spring bloom conditions. We have analysed both $63-150 \mu \mathrm{m}$ and $>150 \mu \mathrm{m}$ size fractions of one core per site for each sampling period. These analyses are combined with numerous environmental measurements such as grain size distribution, sediment oxygenation (oxygen penetration depth, oxygen uptake) and sedimentary organic matter quantity (organic carbon content) and quality (Chl- $a$, amino acids and lipids contents, carbon and nitrogen stable isotopes). The aim of this study is to gain insight of the ecosystem dynamics with regards of changes in river input to the coastal zone. We describe the complex relationship between (1) changes in river discharge including extreme events (floods), (2) changes in environmental conditions in the water column and sediments and (3) the response of benthic foraminiferal faunas in the Rhône prodelta in terms of standing stocks, diversity and composition.

\section{Material and methods}

\subsection{Study area}

The Rhône River flows into the Gulf of Lions, a large crescent-shaped continental shelf located in the NorthWestern Mediterranean Sea (Berné and Gorini, 2005). At the river mouth, a turbid river plume spreads out. According to Naudin et al. (1997), its offshore extension and shape depend on the Rhône outflow (low/high discharge), wind regime (Mistral and Tramontane; Millot, 1999) and the intensity of the North Mediterranean Current flowing westward along the continental slope (Béthoux and Prieur, 1983; Millot, 1990). The mixing between riverine (low salinity) and marine waters (high salinity) in the Rhône channel is typical of a microtidal saltwedge estuary. The salt water forms a wedge in the river bed underneath the freshwater layer. The landward extension of this wedge is mainly controlled by the river discharge. During low water discharge periods (about $500 \mathrm{~m}^{3} \mathrm{~s}^{-1}$ ), the salt intrusion can extend up to $20 \mathrm{~km}$ inland, whereas marine waters are pushed seaward to the river mouth during high water discharge $\left(>3000 \mathrm{~m}^{3} \mathrm{~s}^{-1}\right)$, without any influence on bottom water salinity off the river mouth (Eisma, 1993). The Rhône River carries 90 \% of the terrigeneous material and $80 \%$ of the fresh water introduced into the Gulf of Lions (Durrieu de Madron et al., 2000, 2003). Thanks to these riverine supplies, the Gulf of Lions is one of the most productive areas of the Mediterranean Sea (Diaz, 2000), the Rhône River supplying 50 \% of the total nutrients needed for primary production into the Gulf (Lochet and Leveau, 1990). Phytoplankton primary production is maximal from March to May with Chl- $a$ concentrations in sea-surface waters of $1 \mathrm{mg} \mathrm{Chl}-a \mathrm{~m}^{-3}$ (Bosc et al., 2004). The summer season is 
the most oligotrophic period with $0.1-0.2 \mathrm{mg} \mathrm{Chl}-a \mathrm{~m}^{-3}$ in surface waters. In the Rhône River, riverine phytoplankton blooms also during spring. This riverine production can be exported to the open sea in the surface waters of the river plume (Harmelin-Vivien et al., 2008).

The mean annual flow of the Rhône River is about $1700 \mathrm{~m}^{3} \mathrm{~s}^{-1}$, with maximum discharge values $>3000 \mathrm{~m}^{3} \mathrm{~s}^{-1}$ in autumn and spring during major flood events (Pont et al., 2002). The terrigeneous material carried during these events is transferred to the marine environment essentially in a bottom nepheloid layer above the sea floor, but also in suspension in the surface waters of the river plume (Naudin et al., 1997). Although $30 \%$ of the introduced particles are transferred to the slope and to the deeper basin (Got and Aloisi, 1990), a major part of the riverine terrigeneous input is deposited close to the river outlet, from 0 to $60 \mathrm{~m}$ depth and from 0 to $6 \mathrm{~km}$ off the mouth, thus forming a delta front and a prodeltaic area (Rabineau et al., 2005). This zone is subject to very high deposition rates ranging from 30 to $50 \mathrm{~cm} \mathrm{yr}^{-1}$ (Calmet and Fernandez, 1990; Charmasson et al., 1998; Rabineau et al., 2005).

\subsection{Sediment sampling}

Stations $\mathrm{A}$ and $\mathrm{N}$ were sampled on the $\mathrm{R} / \mathrm{V}$ Téthys II in April 2007 (RiOMar 1 cruise), September 2007 (RIOTECH cruise), May 2008 (CHACCRA-bent 1 cruise) and December 2008 (CHACCRA-bent 2 cruise). The two stations were respectively located at 24 and $67 \mathrm{~m}$ depth in the Rhône prodelta (Fig. 1, Table 1). At each station and during each sampling period, one core $\left(72 \mathrm{~cm}^{2}\right.$ surface area) was recovered with a multicorer MUC 8/100 (Oktopus GmbH) that permits to collect cores with an undisturbed sediment - water interface. We studied live benthic foraminiferal faunas in all cores. Various environmental parameters were also analysed at each site for the different sampling periods.

\subsection{Rhône River discharge and supplies}

Daily Rhône River discharges ( $\mathrm{Q}$ in $\mathrm{m}^{3} \mathrm{~s}^{-1}$ ) in Arles (SORA station, $30 \mathrm{~km}$ from the mouth) were available thanks to the Compagnie Nationale du Rhône (CNR) through a convention with the Institut de Radioprotection et de Sûreté Nucléaire (IRSN) in the EXTREMA ANR project (ANR-06-VULN005, 2007-2010). Suspended particulate material contents (SPM in $\mathrm{mg} \mathrm{l}^{-1}$ ) in the Rhône River were measured daily by the CNR and/or IRSN at the SORA station in Arles in the framework of the ANR CHACCRA and other projects. For each sampling period, we calculated the mean Rhône River discharge $\left(\mathrm{Q}_{\text {mean }}\right)$ and the mean suspended particulate material load $\left(\mathrm{SPM}_{\text {mean }}\right)$ for the 15 days prior to sampling. We also determined the time lapse since the last major flood (i.e. $>3000 \mathrm{~m}^{3} \mathrm{~s}^{-1}$ ) expressed in days.

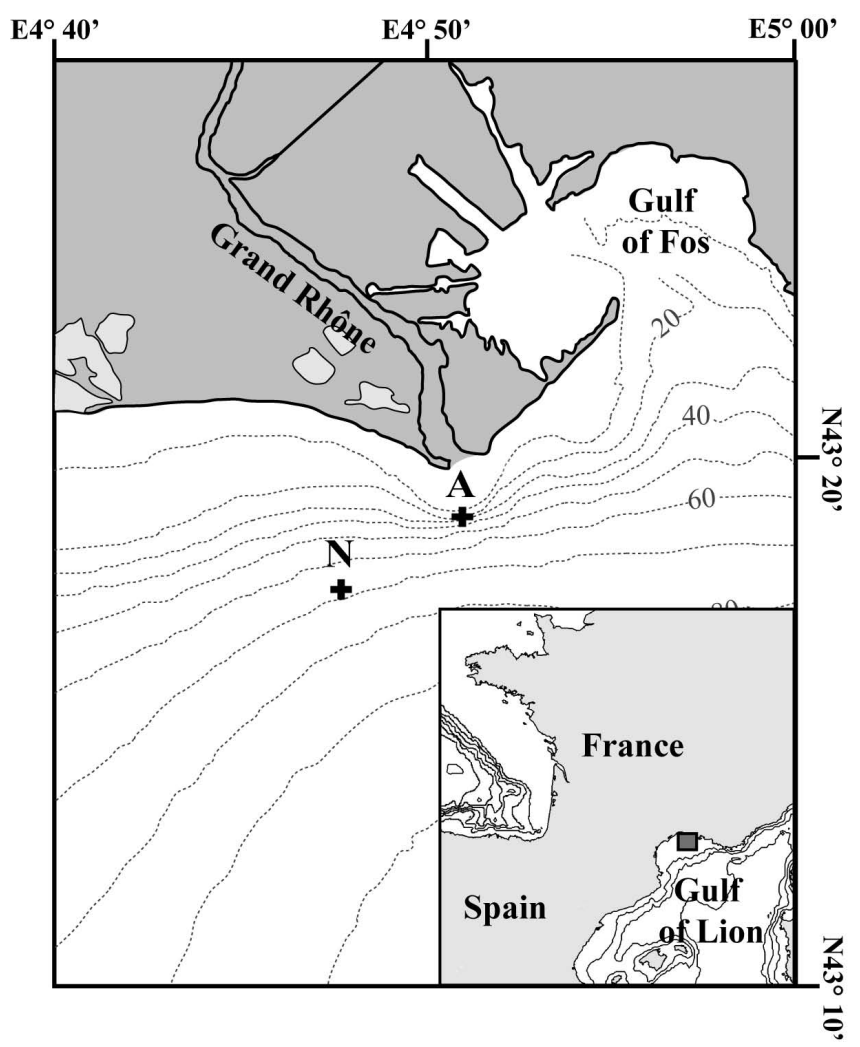

Fig. 1. Study area and location of both investigated Stations A and $\mathrm{N}$.

\subsection{Sediment grain size distribution}

Sediment grain size analyses were performed at both Stations $\mathrm{A}$ and $\mathrm{N}$ in the top $5 \mathrm{~cm}$ of sediment using a Malvern (B Mastersizer 2000 laser microgranulometer. For each analysed sediment level, results are expressed as percentages of clay $(<4 \mu \mathrm{m})$, fine silts $(4-20 \mu \mathrm{m})$, coarse silts $(20-63 \mu \mathrm{m})$, fine sands $(63-200 \mu \mathrm{m})$ and coarse sands $(>200 \mu \mathrm{m})$ and as the median diameter $\mathrm{D}(0.50)$.

\subsection{Geochemical analyses}

For both stations, Total Nitrogen and Organic Carbon concentrations (TN and OC, respectively), total hydrolysable amino acids (THAA) and total lipids contents, and carbon and nitrogen stable isotopic ratios of organic matter $\left(\delta^{13} \mathrm{C}_{\mathrm{OC}}\right.$ and $\delta^{15} \mathrm{~N}$ ) were measured on milled and freeze-dried sediment samples from the top $0-0.5 \mathrm{~cm}$ of one sediment core. Chlorophyll- $a$ (Chl- $a$ ) concentrations were also determined on thawed sediments sampled in the top half-centimetre of three cores (see Bourgeois et al., 2011).

In situ profiles of $\mathrm{O}_{2}$ in the pore water were obtained by a benthic microprofiler using Clark micro-electrodes (Rabouille et al., 2003; Cathalot et al., 2010). Bottom waters were sampled $2 \mathrm{~m}$ above the sea floor by a Niskin bottle, 
Table 1. Location and environmental characteristics of both Stations $A$ and $N$ over the four sampling campaigns. $Q_{m e a n}$ and $S_{P M} M_{m e a n}$ are mean Rhône River discharge and suspended material load, respectively, calculated over the 15 days prior to sampling. $\Delta t /$ last major flood is the time interval since the last Rhône River flood $>3000 \mathrm{~m}^{3} \mathrm{~s}^{-1}$. $T_{\mathrm{BW}}$ and $\left[\mathrm{O}_{2}\right]_{\mathrm{BW}}$ correspond to bottom water temperature and oxygenation, respectively.

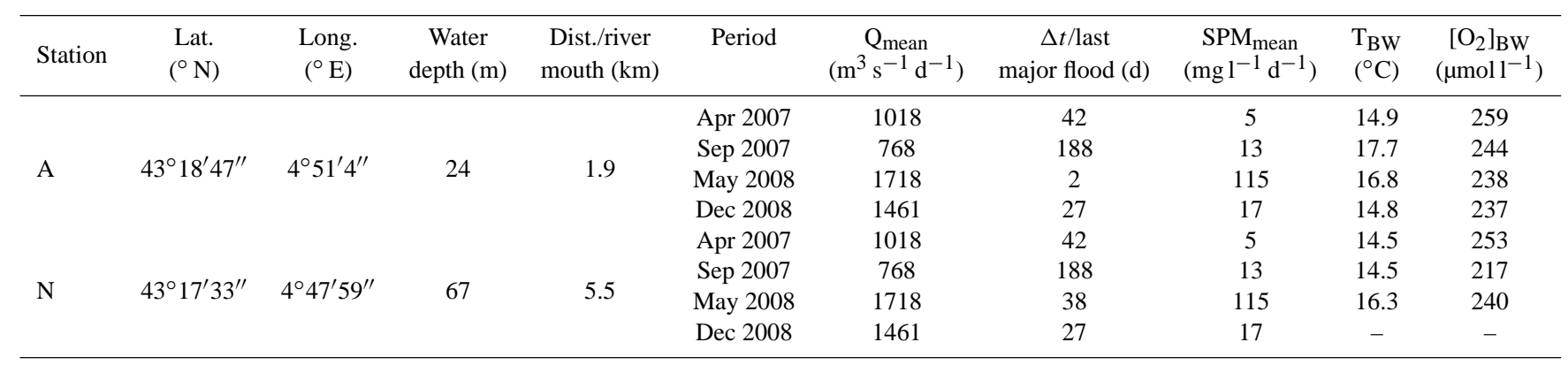

for determination of temperature $\left(T_{\mathrm{BW}}\right)$ and dissolved oxygen $\left(\left[\mathrm{O}_{2}\right]_{\mathrm{BW}}\right)$ (Table 1).

\subsection{Benthic foraminiferal faunas}

For foraminiferal faunal analysis, each replicate core was sliced on board, every $0.5 \mathrm{~cm}$ until $2 \mathrm{~cm}$ depth, and every $1 \mathrm{~cm}$ from 2 to $5 \mathrm{~cm}$ depth. Each sample was preserved in a plastic bottle with a solution of $95 \%$ ethanol and $1 \mathrm{~g} \mathrm{~L}^{-1}$ Rose Bengal stain. In the laboratory, samples were sieved through 63 and $150 \mu \mathrm{m}$ mesh screens and the sieve residues were again preserved in $95 \%$ ethanol. All stained specimens of the $>150 \mu \mathrm{m}$ size fraction were handpicked down to $5 \mathrm{~cm}$ depth under wet conditions under a binocular microscope and stored in micropaleontological slides. Foraminifera belonging to the $63-150 \mu \mathrm{m}$ size fraction were only investigated in the topmost $0.5 \mathrm{~cm}$. Samples of this size fraction were dried and split with an Ottomicrosplitter because of the high standing stocks. All living foraminifera from complete splits were wet-picked until a minimum of 300 individuals was counted. Rose Bengal stain (Walton, 1952; Murray and Bowser, 2000) is commonly used in living foraminiferal studies because of the easy and rapid way of this technique. However, an important methodological problem is that protoplasm of dead foraminifera may be preserved in anoxic sediments, and may still be stained by Rose Bengal (Bernhard, 1988, 2000; Corliss and Emerson, 1990). Consequently, only specimens with all chambers (except the last one) brightly stained pink were counted, and doubtful individuals were compared with perfectly stained individuals of the same species found in more superficial and oxygenated sediment layers. Total living foraminiferal standing stocks were calculated for the $>150 \mu \mathrm{m}(0-5 \mathrm{~cm}$ depth) and $63-150 \mu \mathrm{m}$ size fractions $(0-$ $0.5 \mathrm{~cm}$ ) for each core. These absolute density values are normalised for a sediment surface area of $100 \mathrm{~cm}^{2}$ (D). Species relative abundances (i.e. percentages, \%) calculated for each core allow to define major species (i.e. species $>5 \%$ in at least one core). To quantify the diversity patterns of the foraminiferal faunas, Shannon $(\mathrm{H})$ and Evenness $(\mathrm{E})$ indices were calculated in each core for both size fractions (Hayek and Buzas, 1997; Murray, 2006).

\section{Results}

\subsection{Rhône River discharge and supplies}

The four sampling campaigns were characterised by different Rhône River regimes (Fig. 2, Table 1). The time interval since the last major flood (i.e. Rhône discharge $>3000 \mathrm{~m}^{3} \mathrm{~s}^{-1}$ ) ranged from 2 (May 2008) to 188 days (September 2007). In April 2007, the last flood was recorded $\sim 50$ days before sampling. In September 2007, the mean Rhône River discharge in the 15 days before sampling $\left(\mathrm{Q}_{\text {mean }}\right)$ was minimal with a value of $\sim 770 \mathrm{~m}^{3} \mathrm{~s}^{-1}$. In May 2008, sampling was performed 2 days after the beginning of a major flood (from $\sim 1730 \mathrm{~m}^{3} \mathrm{~s}^{-1}$ on 27 May 2008 to $\sim 3820 \mathrm{~m}^{3} \mathrm{~s}^{-1}$ on 29 May 2008). Finally, in December 2008, sampling took place 27 days after a late fall flood (until $\sim 4800 \mathrm{~m}^{3} \mathrm{~s}^{-1}$ ). Qmean values were maximal during the latter sampling period, with $\sim 1700 \mathrm{~m}^{3} \mathrm{~s}^{-1}$ (May 2008) and $\sim 1450 \mathrm{~m}^{3} \mathrm{~s}^{-1}$ (December 2008). A minimal mean suspended material load $\left(\mathrm{SPM}_{\text {mean }}\right)$ was recorded in April 2007, with only $5 \mathrm{mgl}^{-1} \mathrm{~d}^{-1}$. In May 2008, $\mathrm{SPM}_{\text {mean }}$ was maximal reaching $115 \mathrm{mg} \mathrm{l}^{-1} \mathrm{~d}^{-1}$.

\subsection{Sediment grain size distribution}

At Station A, the median diameter $\mathrm{D}(0.50)$ varied between 6.7 and $67.1 \mu \mathrm{m}$ with time and with sediment depth (Fig. 3a, Table 2). In May, the top 3 centimetres of sediment consisted essentially of fine-grained material with $82-84 \%$ of clay and fine silts $(<20 \mu \mathrm{m})$. Below, clay and fine silts contribution decreased down to $47 \%$. In December 2008, the 


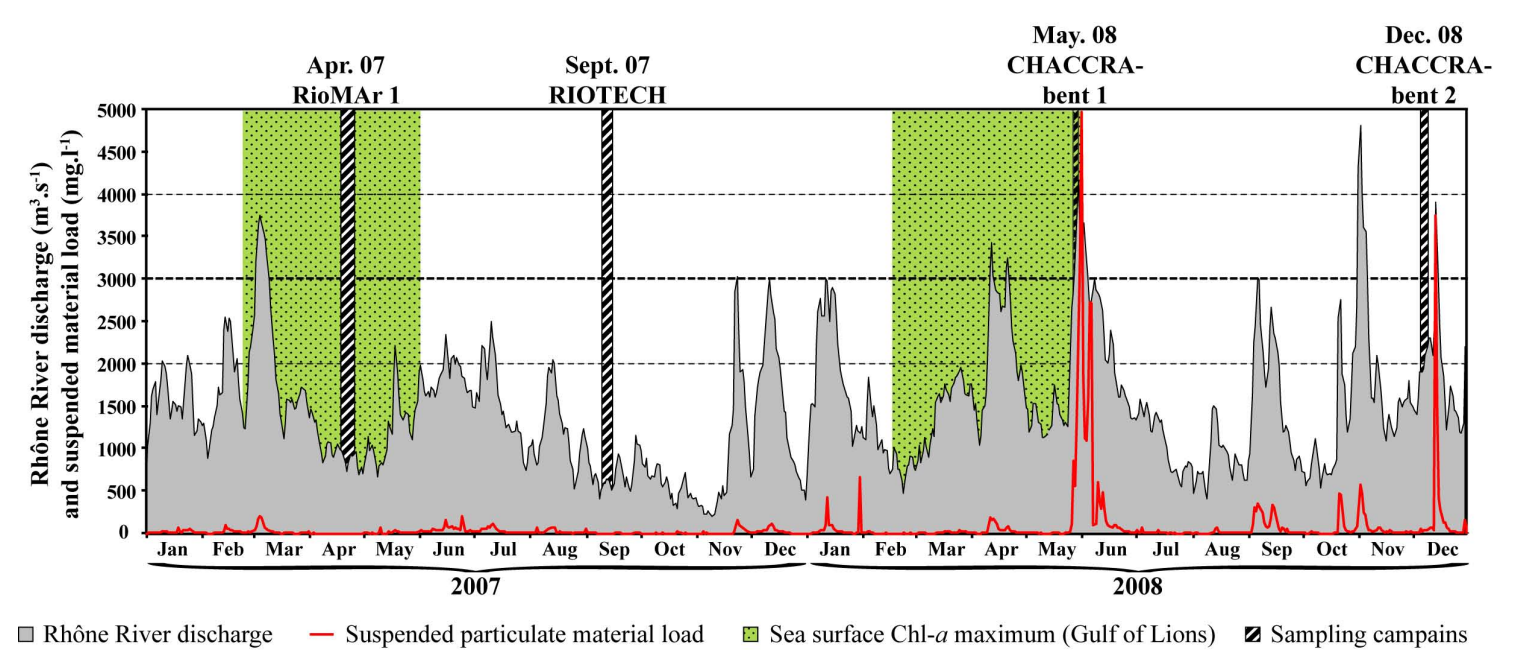

Fig. 2. Mean daily discharge (light-grey area) and suspended particulate material load (red curve) of the Rhône River recorded by the Compagnie Nationale du Rhône and the IRSN at SORA station (Arles), located $\sim 30 \mathrm{~km}$ upstream from the river mouth from January 2007 to December 2008. Different sampling campaigns are represented by black-dashed areas; green dotted areas represent spring blooms in the Gulf of Lions (SeaWIFS images).

sand fraction $(>63 \mu \mathrm{m})$ was predominant in the top $2 \mathrm{~cm}$ of the cores $(51-53 \%)$.

Sediments at Station N showed a large contribution of the fine fraction $(<63 \mu \mathrm{m})$, with 84.9 to $98.3 \%$ of clay and silts over the four periods. The median diameter $\mathrm{D}(0.50)$ ranged between 7.4 and $21.0 \mu \mathrm{m}$ (Fig. 3b, Table 2).

\subsection{Bottom water characteristics - Sediment oxygenation and oxygen uptake}

At Station A, bottom water temperature $\left(T_{\mathrm{BW}}\right)$ varied between 14.8 (December 2008) and $17.7^{\circ} \mathrm{C}$ (September 2007) (Table 1). Bottom waters were well-oxygenated, with values $>200 \mu \mathrm{moll}^{-1}\left(237-259 \mu \mathrm{mol}^{-1}\right)$. Oxygen penetration depth (OPD) was minimal and exhibited minor variation between April 2007, September 2007 and December 2008, with values ranging from 1.4 to $1.7 \mathrm{~mm}$ (Table 3). A deepening of the OPD was observed in May 2008 when a $5.8 \mathrm{~mm}$-thick oxygenated level was observed. Dissolved oxygen uptake (DOU) was maximal in April 2007 and December 2008 with 21.5 and $20.6 \mathrm{mmol} \mathrm{O}_{2} \mathrm{~m}^{-2} \mathrm{~d}^{-1}$, respectively. A minimal uptake was measured in May 2008 with $9.2 \mathrm{mmol} \mathrm{O}_{2} \mathrm{~m}^{-2} \mathrm{~d}^{-1}$.

At Station N, no data are available for December 2008. At the other three sampling periods, bottom water temperature ranged from 14.5 to $16.3^{\circ} \mathrm{C}$. Bottom water oxygen concentration was also high, with values varying between 217 and $253 \mu \mathrm{moll}^{-1}$. OPD was deeper than at Station A, with values ranging from 3.3 to 3.8 in April 2007 and May 2008 to $4.9 \mathrm{~mm}$ in September 2007. DOU was lower than at Station A, with similar values of 9.2 and $9.5 \mathrm{mmol} \mathrm{O}_{2} \mathrm{~m}^{-2} \mathrm{~d}^{-1}$ in April 2007 and May 2008. DOU was minimal in September 2007 with $6.6 \mathrm{mmol} \mathrm{O}_{2} \mathrm{~m}^{-2} \mathrm{~d}^{-1}$.

\subsection{Sedimentary particulate organic matter and chlorophyll- $a$ concentrations}

At Station A, lowest organic carbon (OC) contents in the top half-centimetre of sediment were recorded in May and December 2008, with values of $1.13 \%$ d.w. and $1.22 \%$ d.w., respectively (Fig. 4a, Table 3). The highest concentration was measured in April 2007, with a content of $2.05 \%$ d.w.. Lowest concentrations of the sum of amino acids and lipids were observed in December and May 2008, with values of 1.8 and $1.9 \mathrm{mg} \mathrm{g}^{-1}$ d.w. (i.e. 14.7 and $16.7 \%$ of the OC, respectively). The highest content $\left(4.2 \mathrm{mg} \mathrm{g}^{-1} \mathrm{~d} . \mathrm{w}, 20.4 \%\right.$ of the OC) was recorded in April 2007. $\delta^{13} \mathrm{C}_{\mathrm{OC}}$ ranged from $-27.18 \%$ in April 2007 to $-24.79 \%$ in December 2008. Intermediate values of -26.64 to $-26.30 \%$ were recorded in September 2007 and May 2008. The C:N ratio showed important variations, with values ranging between 12.5 in September 2007 and 28.1 in December 2008. Unfortunately, no $\delta^{15} \mathrm{~N}$ value is available for December 2008. During the three other sampling periods, $\delta^{15} \mathrm{~N}$ was less variable than $\delta^{13} \mathrm{C}_{\mathrm{OC}}$, values ranging between 2.90 and $3.92 \%$. Chl- $a$ concentrations in the top first centimetre of the sediment var-

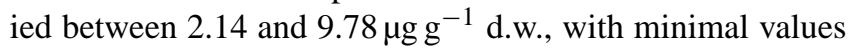
in April 2007 and maximum contents in December 2008.

At Station N, OC content was minimal in May 2008 with only $1.00 \%$ d.w., and reached its maximum value in April 2007 and December 2008 with $1.4 \%$ d.w. (Fig. 4b, Table 3). The sum of amino acids and lipids had comparable concentrations in April 2007, September 2007 and May 2008, with values of $2.7 \mathrm{mg} \mathrm{g}^{-1} \mathrm{~d}$.w. (from 19.2 to $27.0 \%$ of the OC). The highest concentrations were recorded in December 2008 with $3.8 \mathrm{mg} \mathrm{g}^{-1}$ d.w. (27.8\% of the OC). Also $\delta^{13} \mathrm{C}_{\mathrm{OC}}$ and $\delta^{15} \mathrm{~N}$ were very constant, ranging from -26.12 
(a) Station A

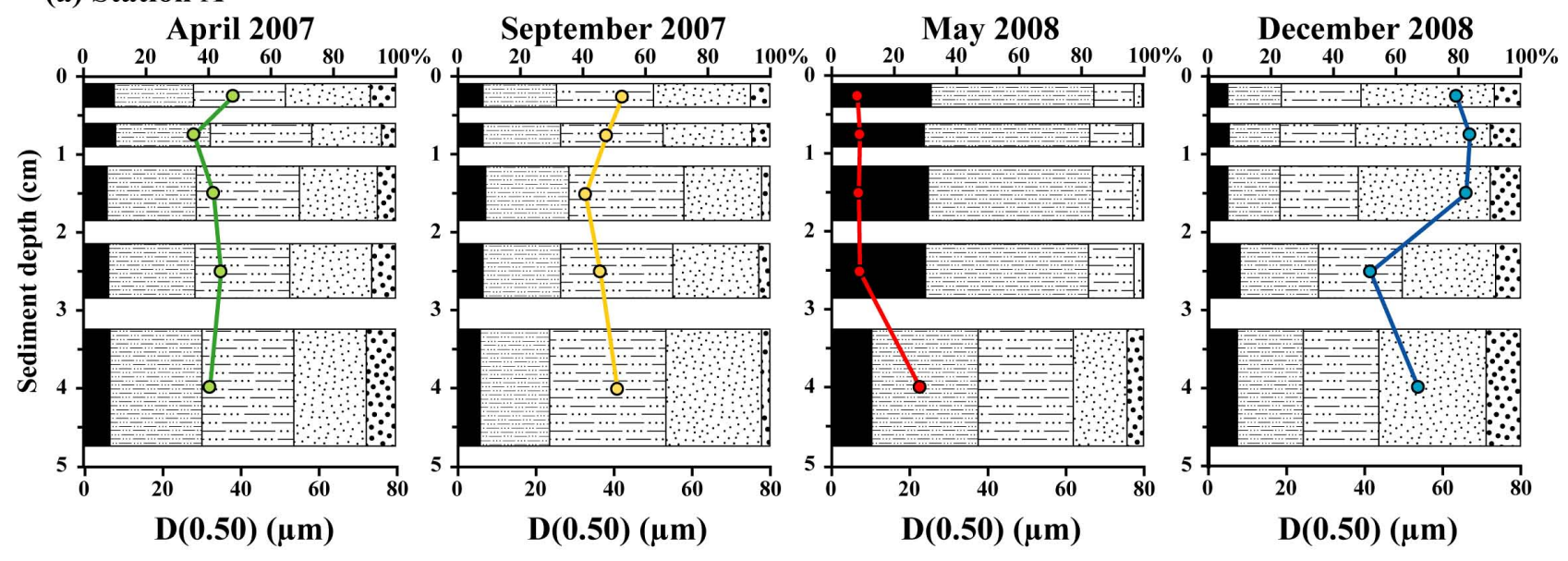

Clay $(<4 \mu \mathrm{m}) \quad \therefore$ Fine silts $(4-20 \mu \mathrm{m}) \quad \because$ Coarse silts $(20-63 \mu \mathrm{m}) \quad \therefore$ Fine sands $(63-200 \mu \mathrm{m}) \quad \because \because \mathrm{Coarse}$ sands $(>200 \mu \mathrm{m})$

(b) Station $\mathbf{N}$

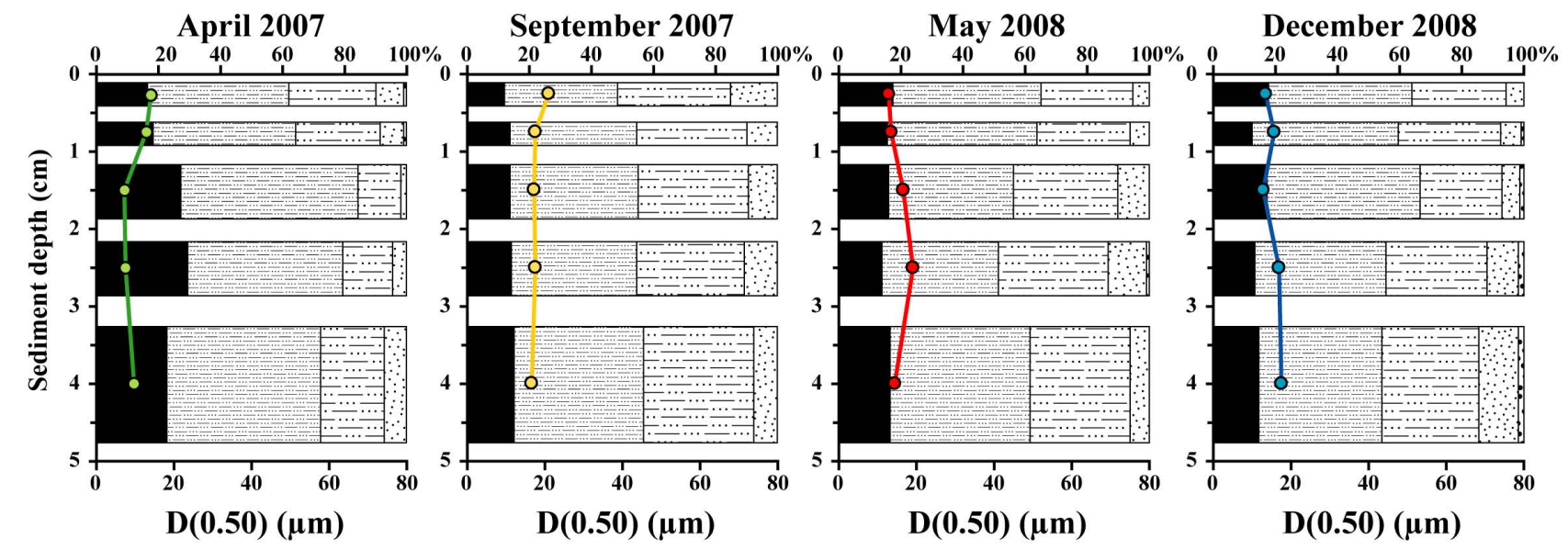

Fig. 3. Sediment composition along the top $5 \mathrm{~cm}$ of the cores at both Stations A (a) and N (b). Horizontal bars represent clay, fine silts, coarse silts, fine sands and coarse sands contributions. Curves correspond to sediment median diameter $\mathrm{D}(0.50)$ for each sediment interval.

to $-25.82 \%$ and from 3.46 to $3.90 \%$, respectively. The lowest C:N ratio was measured in May 2008 with a value of 12.0. Maximal values were recorded in December 2008 and April 2007, with 16.2 and 17.4, respectively. Sedimentary Chl$a$ content showed small variations between the investigated sampling dates. The highest concentration was measured in April 2007 with $2.57 \mu \mathrm{g} \mathrm{g}^{-1} \mathrm{~d}$.w., whereas values were fairly similar for the three other sampling periods, ranging between 1.23 and $1.62 \mu \mathrm{g} \mathrm{g}^{-1}$ d.w.

\subsection{Foraminiferal faunas}

\subsubsection{Station A (24 m)}

In the $>150 \mu \mathrm{m}$ fauna, total foraminiferal standing stocks in the 0 to $5 \mathrm{~cm}$ sediment interval varied from 286 (September 2007) to 7767 ind./100 $\mathrm{cm}^{2}$ (May 2008) (Fig. 5a). The species richness $\mathrm{S}$ varied from 8 (May 2008) to 19 (April 2007) (Fig. 5b). The Shannon index $\mathrm{H}$ ranged from $0.11-$ 0.33 in May and December 2008 to $1.47-1.77$ in April and September 2007 (Fig. 5c). The Evenness index followed the same trend with minimum values of $0.10-0.12$ in May and December 2008 and maximal index in September 2007 (0.35) (Fig. 5d). 
Table 2. Sediment grain size analyses performed in the top $5 \mathrm{~cm}$ of the cores of both Stations A and $\mathrm{N}$ over the four sampling campaigns: percentages of clay, fine silts, coarse silts, fine sands and coarse sands, and sediment median diameter $\mathrm{D}(0.50)$ for each analysed sediment interval.

\begin{tabular}{|c|c|c|c|c|c|c|c|c|}
\hline Station & $\begin{array}{l}\text { Sampling } \\
\text { period }\end{array}$ & $\begin{array}{l}\text { Sediment } \\
\text { level }(\mathrm{cm})\end{array}$ & $\begin{array}{l}\text { Clays } \\
(<4 \mu \mathrm{m})\end{array}$ & $\begin{array}{l}\text { Fine silts } \\
(4-20 \mu \mathrm{m})\end{array}$ & $\begin{array}{l}\text { Coarse silts } \\
(20-63 \mu \mathrm{m})\end{array}$ & $\begin{array}{l}\text { Fine sands } \\
(63-200 \mu \mathrm{m})\end{array}$ & $\begin{array}{l}\text { Coarse sands } \\
(>200 \mu \mathrm{m})\end{array}$ & $\begin{array}{l}\text { Median diameter } \\
\mathrm{D}(0.50)(\mu \mathrm{m})\end{array}$ \\
\hline \multirow[t]{20}{*}{ A } & \multirow[t]{5}{*}{ April 2007} & $0-0.5$ & 10 & 26 & 29 & 27 & 8 & 38.5 \\
\hline & & $0.5-1$ & 10 & 31 & 33 & 22 & 4 & 28.5 \\
\hline & & $1-2$ & 8 & 28 & 33 & 25 & 6 & 33.3 \\
\hline & & $2-3$ & 8 & 28 & 30 & 26 & 8 & 35.3 \\
\hline & & $3-5$ & 9 & 29 & 29 & 23 & 9 & 32.3 \\
\hline & \multirow[t]{5}{*}{ September 2007} & $0-0.5$ & 8 & 24 & 31 & 31 & 6 & 42.1 \\
\hline & & $0.5-1$ & 8 & 25 & 33 & 29 & 6 & 38.3 \\
\hline & & $1-2$ & 9 & 27 & 37 & 25 & 3 & 32.8 \\
\hline & & $2-3$ & 8 & 25 & 36 & 27 & 3 & 36.7 \\
\hline & & $3-5$ & 7 & 22 & 37 & 31 & 3 & 41.1 \\
\hline & \multirow[t]{5}{*}{ May 2008} & $0-0.5$ & 32 & 52 & 12 & 3 & 1 & 6.7 \\
\hline & & $0.5-1$ & 30 & 53 & 14 & 3 & 1 & 7.2 \\
\hline & & $1-2$ & 31 & 53 & 13 & 3 & 1 & 7.0 \\
\hline & & $2-3$ & 30 & 52 & 14 & 3 & 0 & 7.3 \\
\hline & & $3-5$ & 13 & 34 & 31 & 17 & 5 & 22.8 \\
\hline & \multirow[t]{5}{*}{ December 2008} & $0-0.5$ & 6 & 17 & 26 & 43 & 8 & 63.7 \\
\hline & & $0.5-1$ & 7 & 16 & 24 & 43 & 10 & 67.1 \\
\hline & & $1-2$ & 6 & 17 & 25 & 42 & 10 & 66.3 \\
\hline & & $2-3$ & 10 & 25 & 27 & 30 & 8 & 41.7 \\
\hline & & $3-5$ & 9 & 21 & 24 & 35 & 11 & 53.8 \\
\hline \multirow[t]{20}{*}{$\mathrm{N}$} & \multirow[t]{5}{*}{ April 2007} & $0-0.5$ & 17 & 45 & 28 & 9 & 1 & 14.0 \\
\hline & & $0.5-1$ & 18 & 46 & 27 & 8 & 1 & 12.9 \\
\hline & & $1-2$ & 27 & 57 & 14 & 2 & 0 & 7.4 \\
\hline & & $2-3$ & 29 & 50 & 16 & 5 & 0 & 7.4 \\
\hline & & $3-5$ & 23 & 50 & 20 & 7 & 0 & 9.7 \\
\hline & \multirow[t]{5}{*}{ September 2007} & $0-0.5$ & 12 & 36 & 36 & 15 & 0 & 21.0 \\
\hline & & $0.5-1$ & 14 & 41 & 35 & 10 & 0 & 17.6 \\
\hline & & $1-2$ & 14 & 41 & 36 & 9 & 0 & 17.4 \\
\hline & & $2-3$ & 14 & 40 & 35 & 11 & 0 & 17.6 \\
\hline & & $3-5$ & 15 & 42 & 35 & 8 & 0 & 16.5 \\
\hline & \multirow[t]{5}{*}{ May 2008} & $0-0.5$ & 17 & 48 & 30 & 5 & 0 & 12.8 \\
\hline & & $0.5-1$ & 15 & 48 & 30 & 6 & 0 & 13.6 \\
\hline & & $1-2$ & 16 & 40 & 33 & 10 & 0 & 16.5 \\
\hline & & $2-3$ & 14 & 38 & 35 & 13 & 1 & 19.3 \\
\hline & & $3-5$ & 16 & 45 & 32 & 6 & 0 & 14.4 \\
\hline & \multirow[t]{5}{*}{ December 2008} & $0-0.5$ & 17 & 47 & 30 & 6 & 0 & 13.6 \\
\hline & & $0.5-1$ & 12 & 47 & 33 & 7 & 1 & 15.8 \\
\hline & & $1-2$ & 17 & 49 & 26 & 6 & 1 & 12.8 \\
\hline & & $2-3$ & 13 & 43 & 32 & 10 & 2 & 17.1 \\
\hline & & $3-5$ & 14 & 40 & 31 & 13 & 2 & 17.4 \\
\hline
\end{tabular}

A total of 31 taxa were recognised at Station A, with 5 major species: Ammonia tepida, Nonion fabum, Nonionella turgida, Eggerella scabra and Leptohalysis scottii (Fig. 6a). In April 2007, the fauna was characterised by elevated percentages of L. scottii (>50\%), N. turgida $(18.7 \%)$, E. scabra (12.5\%) and N. fabum (9.8\%). In September 2007, the contribution of $L$. scottii was much lower $(8.3 \%)$, whereas A. tepida accounted for $50.5 \%$ of the total fauna. In May
2008, the abundance of $L$. scottii reached 7538 ind. $/ 100 \mathrm{~cm}^{2}$, i.e. $98.2 \%$ of the total assemblage. In December 2008, this species was absent whereas A. tepida strongly dominated the fauna, with 1438 ind. $/ 100 \mathrm{~cm}^{2}$ or $93.9 \%$ of the total assemblage.

In the $63-150 \mu \mathrm{m}$ size fraction, the foraminiferal abundances in the top most $0.5 \mathrm{~cm}$ ranged from $\sim 140$ (May 2008) to $\sim 5120$ ind. $/ 100 \mathrm{~cm}^{2}$ (April 2007) (Fig. 5a). The species 
Table 3. Results of the different environmental parameters analysed within sediments of both Stations A and N over the four sampling campaigns. Oxygen penetration depth (OPD), dissolved oxygen uptake (DOU) and analyses on particulate organic matter from the top half-centimetre of sediment: organic carbon (OC), carbon and nitrogen stable isotopic ratios $\left(\delta^{13} \mathrm{C}_{\mathrm{OC}}\right.$ vs. $\left.\delta^{15} \mathrm{~N}\right)$, sum of lipids and total hydrolysable amino-acids (THAA) contents for dry-weight sediment (d.w.) and contribution to the OC (\% OC).

\begin{tabular}{|c|c|c|c|c|c|c|c|c|c|c|}
\hline Station & Period & $\begin{array}{l}\text { OPD } \\
(\mathrm{mm})\end{array}$ & $\begin{array}{c}\text { DOU } \\
\left(\mathrm{mmol} \mathrm{O}_{2} \mathrm{~m}^{-2} \mathrm{~d}^{-1}\right)\end{array}$ & $\begin{array}{c}\text { OC } \\
\text { (\% d.w.) }\end{array}$ & $\begin{array}{c}\mathrm{C}: \mathrm{N} \\
\text { (Atomic ratio) }\end{array}$ & $\begin{array}{c}\delta^{13} \mathrm{C}_{\mathrm{OC}} \\
(\% \circ)\end{array}$ & $\begin{array}{l}\delta^{15} \mathrm{~N} \\
(\% o)\end{array}$ & $\begin{array}{l}\text { Lipids }+\mathrm{T} \\
\text { (mg g }{ }^{-1} \text { d.w.) }\end{array}$ & $\begin{array}{l}\mathrm{HAA} \\
(\% \mathrm{OC})\end{array}$ & $\begin{array}{c}\text { Chl- } a \\
\left(\mu \mathrm{g} \mathrm{g}^{-1}\right)\end{array}$ \\
\hline \multirow[t]{4}{*}{ A } & Apr.07 & $1.4 \pm 0.2$ & $21.5 \pm 3.9$ & 2.05 & 15.2 & -27.18 & 3.58 & 4.2 & 20.4 & 9.78 \\
\hline & Sep 07 & $1.7 \pm 0.1$ & $15.3 \pm 1.5$ & 1.40 & 12.5 & -26.64 & 3.92 & 3.7 & 26.5 & 4.66 \\
\hline & May 08 & $5.8 \pm 0.8$ & $9.2 \pm 3.1$ & 1.13 & 14.8 & -26.3 & 2.90 & 1.9 & 16.7 & 3.07 \\
\hline & Dec 08 & $1.6 \pm 0.3$ & $20.6 \pm 2.6$ & 1.22 & 28.1 & -24.79 & - & 1.8 & 14.7 & 2.14 \\
\hline \multirow[t]{4}{*}{$\mathrm{N}$} & Apr 07 & $3.3 \pm 0.6$ & $9.5 \pm 1.2$ & 1.42 & 17.4 & -25.94 & 3.89 & 2.7 & 19.2 & 2.57 \\
\hline & Sep 07 & $4.9 \pm 1.1$ & $6.6 \pm 0.9$ & 1.20 & 13.2 & -25.82 & 3.90 & 2.7 & 22.9 & 1.23 \\
\hline & May 08 & $3.8 \pm 0.6$ & $9.2 \pm 1.9$ & 1.00 & 12.0 & -26.115 & 3.46 & 2.7 & 27.0 & 1.62 \\
\hline & Dec 08 & - & - & 1.36 & 16.2 & -25.88 & 3.67 & 3.8 & 27.8 & 1.47 \\
\hline
\end{tabular}

richness S varied from 1 (May 2008) to 21 (April 2007) (Fig. 5b). A maximal Shannon index was recorded in April and September 2007, with values of 2.11 and 2.04, respectively. The lowest diversity was observed in May 2008 when only one species was identified $(\mathrm{H}=0)$ (Fig. 5c). Except for the peculiar period of May 2008, the Evenness index was fairly constant with values ranging between 0.37 and 0.43 (Fig. 5d).

The foraminiferal faunal composition was quite variable. A total of 29 taxa were recognised, with 8 species presenting relative abundances $>5 \%$ in at least one core: Ammonia tepida, Bolivina dilatata, Haynesina germanica, Nonionella stella, Nonionella turgida, Stainforthia fusiformis, Leptohalysis scottii and Psammosphaera fusca (Fig. 6b). In April 2007, foraminiferal faunas were characterised by $L$. scottii $(\sim 26.5 \%)$, S. fusiformis $(\sim 21 \%)$ and B. dilatata $(\sim 16 \%)$. We noted the presence of $N$. turgida $(\sim 11.5 \%)$ and N. stella $(\sim 8 \%)$. In September 2007, P. fusca accounted for $\sim 45 \%$ of total living faunas, and $L$. scotti was relatively abundant $(\sim 17 \%)$. In May 2008 , foraminiferal faunas were totally dominated by $L$. scottii which composed $100 \%$ of the total living assemblage. In December 2008, L. scottii was low frequent $(\sim 3 \%)$, whereas A. tepida dominated the fauna $(\sim 43.5 \%)$. Psammosphaera fusca was the second most abundant species with a relative abundance of $\sim 30 \%$. $H$. germanica accounted for $\sim 6.5 \%$ of the total living fauna.

\subsubsection{Station $N(67 \mathrm{~m})$}

In the $>150 \mu \mathrm{m}$ size fraction, foraminiferal abundances varied between 1092 (April 2007) and 2753 ind./100 $\mathrm{cm}^{2}$ (May 2008) (Fig. 7a). The number of taxa varied between 37 (May 2008) and 59 (April 2007) (Fig. 7b). The Shannon and Evenness indices were quite similar, with values ranging from 2.13 to 2.63 and from 0.23 to 0.29 , respectively (Fig. $7 \mathrm{c}-\mathrm{d}$ ).

A total of 72 species was recognised, with 9 major species: Nonion fabum, Nonionella turgida, Rectuvige- rina phlegeri, Valvulineria bradyana, Clavulina cylindrica, Cribrostomoides wiesneri, Eggerella scabra, Leptohalysis scottii and Nouria polymorphinoides (Fig. 8a). In April 2007, agglutinated taxa were dominant $(64.4 \%)$ with $E$. scabra $(45.9 \%), C$. cylindrica $(7.4 \%)$ and C. wiesneri (5.1\%). In September 2007, C. cylindrica $(10.7 \%)$ and $E$. scabra $(18.3 \%)$ were abundant, together with $V$. bradyana $(21.2 \%)$, N. fabum $(13.7 \%)$, R. phlegeri $(7.1 \%)$ and N. polymorphinoides $(5.6 \%)$. In May 2008, high percentages of $E$. scabra $(20.0 \%)$, V. bradyana (19.2\%), but also N. turgida $(14.7 \%)$ were observed. In December 2008, high contributions of $N$. polymorphinoides $(15.2 \%)$, R. phlegeri $(11.1 \%)$ and $L$. scottii (5.3\%) were noticed.

In the $63-150 \mu \mathrm{m}$ fauna, foraminiferal standing stocks ranged between $\sim 2580$ (December 2008) and $\sim 11640$ ind./100 $\mathrm{cm}^{2}$ May 2008) (Fig. 7a). The species richness S varied from 40 (April 2007, May and December 2008) to 59 (September 2007) (Fig. 7b). Comparable Shannon index $\mathrm{H}$ values were measured during the four periods, between 2.90 and 3.11 (Fig. 7c). The Evenness index showed quite similar values in April 2007, May and December 2008 (0.45-0.53), and a minimum of 0.38 recorded in September 2007 (Fig. 7d).

A total of 57 taxa were recognised at this station, with 10 species accounting for more than $5 \%$ of total living faunas in at least one core: Bolivina dilatata, Bolivina seminuda, Bolivina spathulata, Hopkinsina atlantica, Nonionella iridea, Nonionella turgida, Rectuvigerina phlegeri, Textularia porrecta, Eggerella scabra and Leptohalysis scottii (Fig. 8b). In April 2007, foraminiferal faunas were characterised by a high contribution of $B$. dilatata $(\sim 21 \%), N$. turgida $(\sim 7.5 \%)$ and $H$. atlantica $(\sim 7 \%)$. In September 2007, H. atlantica $(\sim 8.5 \%)$ and $N$. turgida $(\sim 6.5 \%)$ were associated with B. spathulata $(\sim 8 \%), R$. phlegeri $(\sim 8 \%)$ and E. scabra $(\sim 13.5 \%)$. In May 2008 , N. turgida $(\sim 16 \%)$ and $L$. scottii $(\sim 12 \%)$ were the most abundant species, together with $N$. iridea $(\sim 11.5 \%)$ and $T$. porrecta $(\sim 7 \%)$. 
(a) Station A (z=20 m)
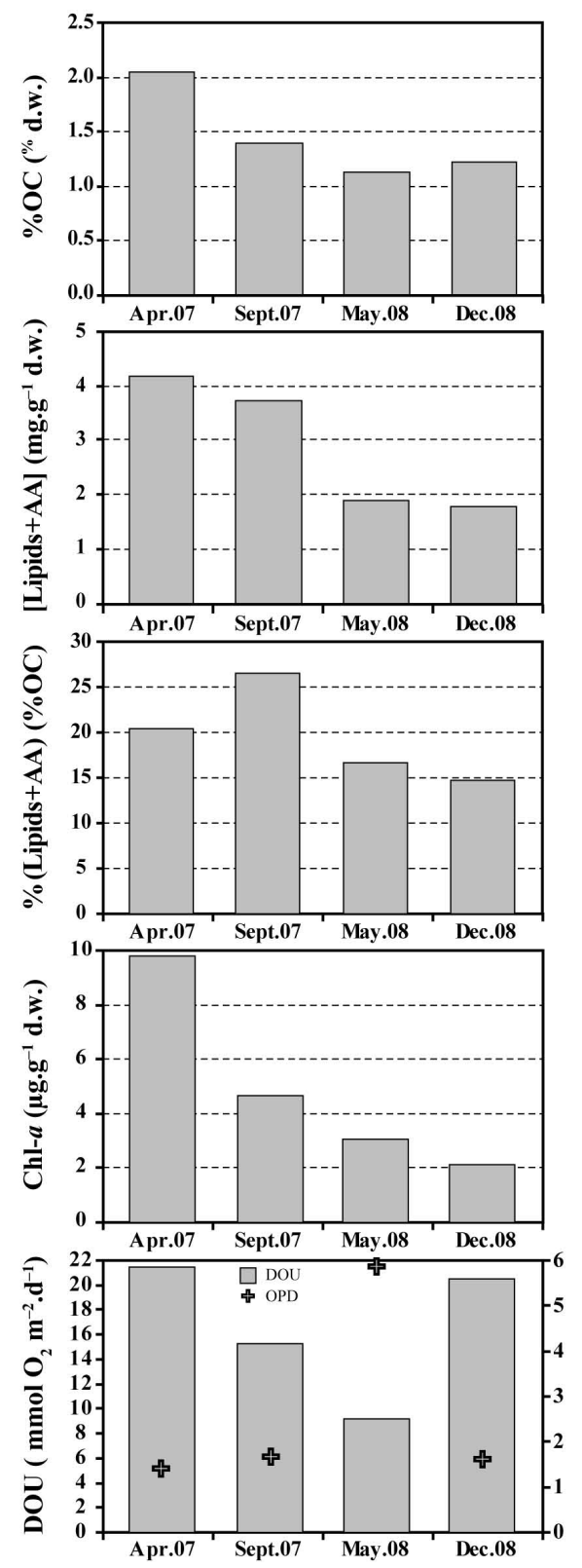

(b) Station N (z=68 m)
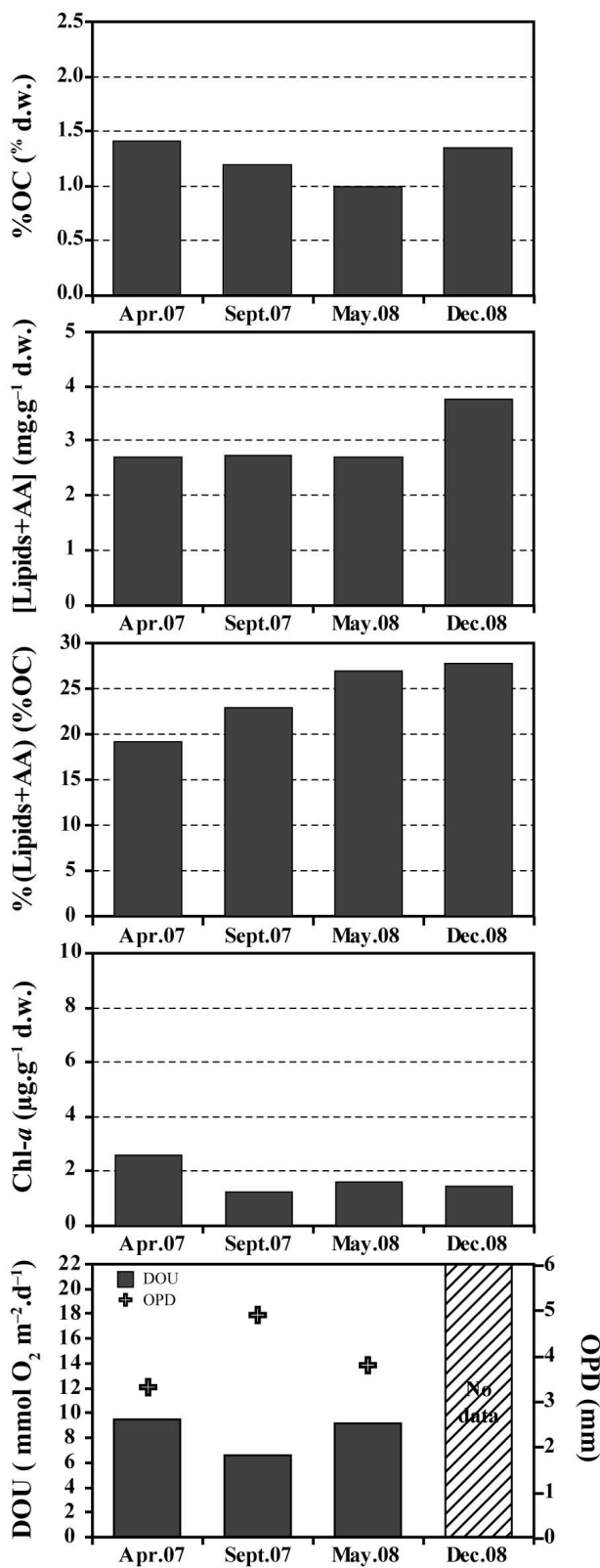

Fig. 4. Descriptors of the organic matter and oxygen parameters measured at both Stations A (a) and N (b).

Finally, in December 2008, high abundances of B. seminuda $(\sim 5.5 \%)$ and $T$. porrecta $(\sim 12 \%)$ were recorded.

\section{Discussion}

\subsection{Environmental setting}

The overall environmental dataset shows contrasted conditions for the four sampling periods and between the two investigated stations. In all investigated periods, the sedi- ment at Station A (24 m depth) displayed important changes of grain size distribution and a high content in OC, lipids, amino acids and Chl- $a$ in comparison with the deeper Station N (67 m depth). This reflects a concentration of organicrich deposits close to the Rhône River mouth, in agreement with observations presented in previous studies (Lansard et al., 2009; Cathalot et al., 2010; Goineau et al., 2011).

At Station A, despite obvious sediment grain size differences between May $(\mathrm{D}(0.50)=6.7 \mu \mathrm{m})$ and December $2008(\mathrm{D}(0.50)=63.7 \mu \mathrm{m}), \mathrm{OC}$ and labile organic compounds show quite similar contents in the top sediment cores of both 
(a) Foraminiferal abundance $D$

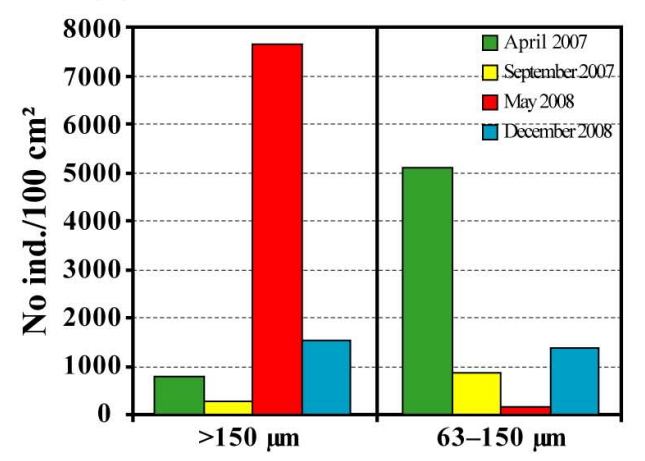

(c) Shannon index $\mathrm{H}$

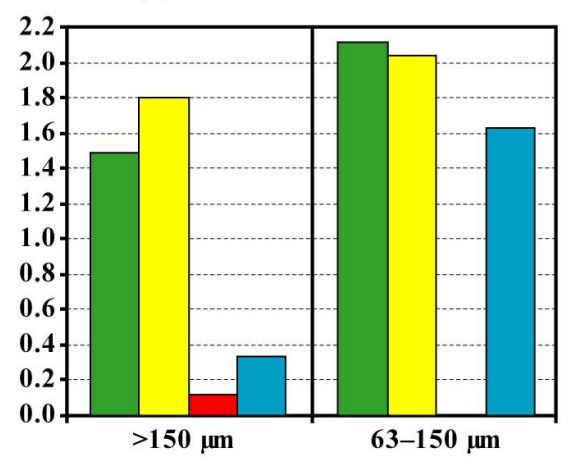

(b) Species richness $\mathrm{S}$

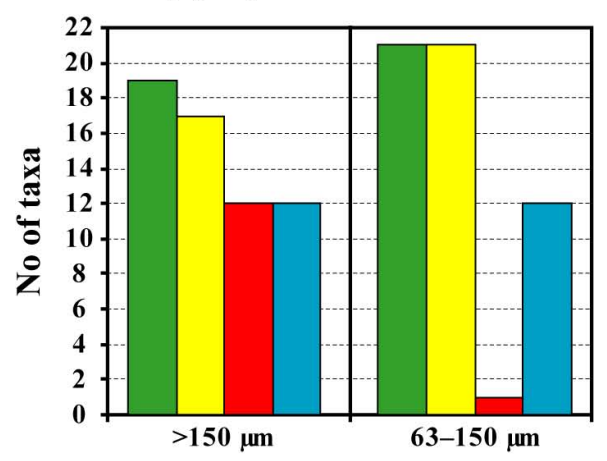

(d) Evenness index E

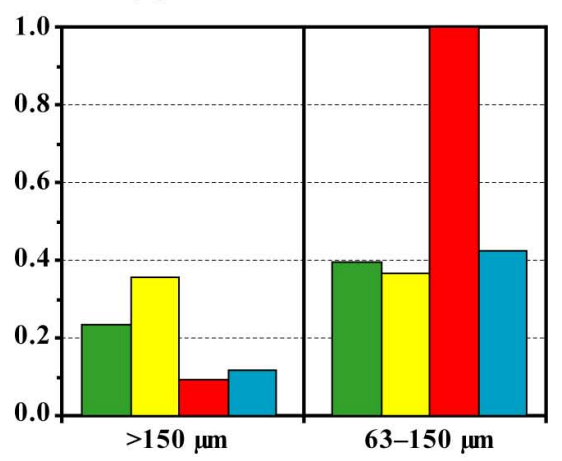

Fig. 5. Foraminiferal abundance D standardised for a surface area of $100 \mathrm{~cm}^{2}$ (core surface: $72 \mathrm{~cm}^{2}$; sediment depth: $0.5 \mathrm{~cm}$ for the $63-$ $150 \mu \mathrm{m}$ size fraction and $5 \mathrm{~cm}$ for the $>150 \mu \mathrm{m}$ size fraction) (a), species richness $\mathrm{S}$ (b), Shannon index H (c) and Evenness index E (d) of the total living foraminiferal faunas in the $>150 \mu \mathrm{m}$ and $63-150 \mu \mathrm{m}$ size fractions at Station A for the four sampling periods.

periods. Similarly, when considering the two other sampling periods (April and September 2007), very close DOU values are recorded in the silty $(\mathrm{D}(0.50)=38.5 \mu \mathrm{m})$ and in the sandy sediments $(\mathrm{D}(0.50)=63.7 \mu \mathrm{m})$ of April 2007 and December 2008, respectively. On the contrary, sediments with similar grain size characteristics (i.e. April and September 2007: $\mathrm{D}(0.50)=38.5-42.1 \mu \mathrm{m})$ present quite different DOU. Therefore, no clear correlation exists between sediment grain size, organic matter content and bio-geochemical processes related to its mineralisation.

In Figure $9, \delta^{13} \mathrm{C}_{\mathrm{OC}}$ has been plotted versus $\delta^{15} \mathrm{~N}$ for both stations and all sampling periods, together with isotopic signatures of different potential particulate organic matter (POM) sources in our study area (Darnaude et al., 2004; Harmelin-Vivien et al., 2008; Kerhervé et al., 2012). Both Stations A and N plot between Rhône River and Offshore sea water POM, but much closer to the Rhône source (low $\delta^{13} \mathrm{C}_{\mathrm{OC}}$ ). However, important isotopic variations were recorded at Station A, with measures plotting either close to "Rhône POM" (i.e. mixture between riverine phytoplankton, vascular plants and soil detritus) or to "terrestrial detritus" (i.e. vascular plants and soil detritus) end members. In April and September 2007, both sampled during low Rhône discharge condi- tions $\left(\mathrm{Q}_{\text {mean }}<1000 \mathrm{~m}^{3} \mathrm{~s}^{-1}\right.$; $\left.\mathrm{SPM}_{\text {mean }}<15 \mathrm{mg} \mathrm{l}^{-1} \mathrm{~d}^{-1}\right)$, sedimentary organic matter $(\mathrm{OM})$ measured at Station A plotted close to the Rhône POM end-member. Therefore, the maximal sediment Chl- $a$ contents measured during these sampling periods suggest a major contribution of continental $\mathrm{OM}$ and riverine phytoplankton. On the contrary, May and December 2008, sampled during and after a flood $\left(\mathrm{Q}_{\text {mean }}>1400 \mathrm{~m}^{3} \mathrm{~s}^{-1} ; \mathrm{SPM}_{\text {mean }}=17\right.$ to $\left.115 \mathrm{mg} \mathrm{l}^{-1} \mathrm{~d}^{-1}\right)$, showed a stronger contribution of terrestrial plant detritus. According to Cathalot et al. (2010) and Kerhervé et al. (2012), the slightly higher $\delta^{13} \mathrm{C}_{\mathrm{OC}}$ values $(>-26.5 \%$ o recorded after the flood in May also pointed out the contribution of soil-derived organic material brought by the river. Station $\mathrm{N}$ also received an organic matter with a strong contribution of the Rhône-derived organic detritus. The isotopic signatures were comparable for the four sampling periods, suggesting a weaker impact of fluctuating Rhône River discharge compared to Station A.

$\delta^{13} \mathrm{C}_{\mathrm{OC}}$ versus N:C atomic ratio is presented on Fig. 10 together with complementary measurements performed in the Rhône prodelta in October 2004, April 2005 (23-68 m depth, $\sim 1$ to $8 \mathrm{~km}$ off the river mouth; Tesi et al., 2007), June 2005 (20-98 $\mathrm{m}$ depth, $\sim 2$ to $16 \mathrm{~km}$ off the mouth; Lansard et al., 2009) and September 2006 (18-100 m depth, $\sim 1$ to $22 \mathrm{~km}$ off 
(a) $>150 \mu \mathrm{m}$ size fraction

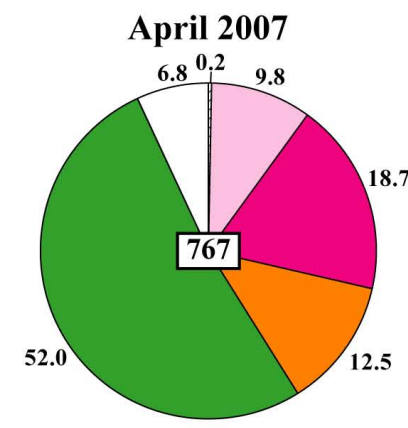

Ammonia tepida

Nonion fab um

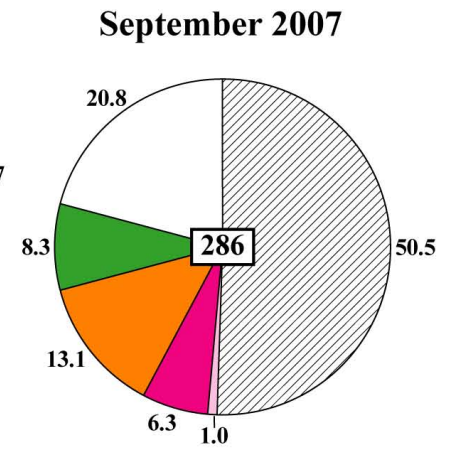

Nonionella turgida

Eggerella scabra

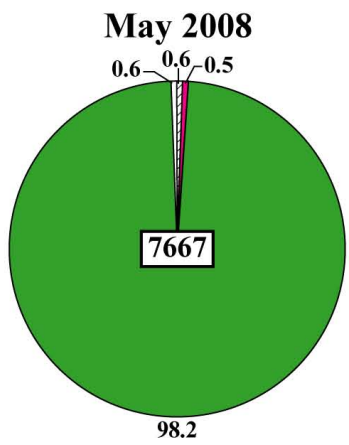

Leptohalysis scottii

Others $<\mathbf{5 \%}$

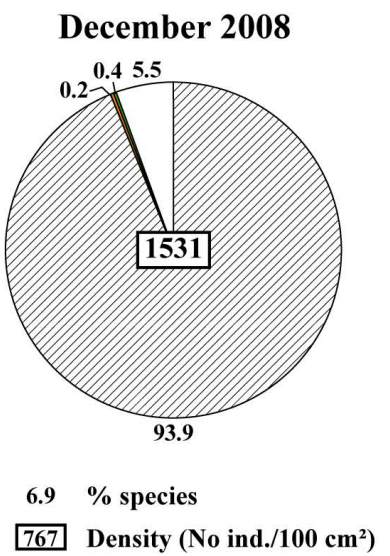

(b) 63-150 $\mu \mathrm{m}$ size fraction

April 2007

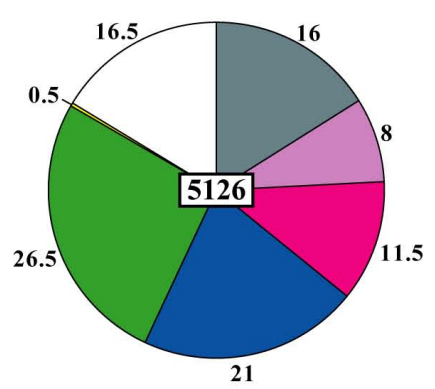

Ammonia tepida

Bolivina dilatata

Haynesina germanica

\section{September 2007}

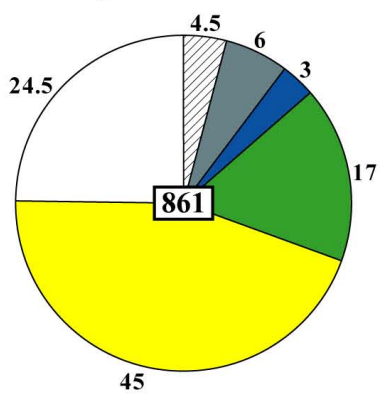

Nonionella stella

Nonionella turgida

Stainforthia fusiformis

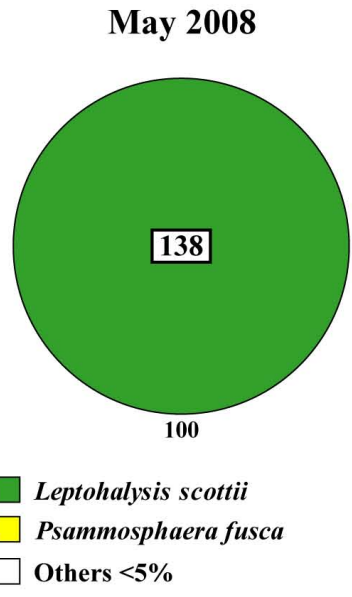

\section{December 2008}

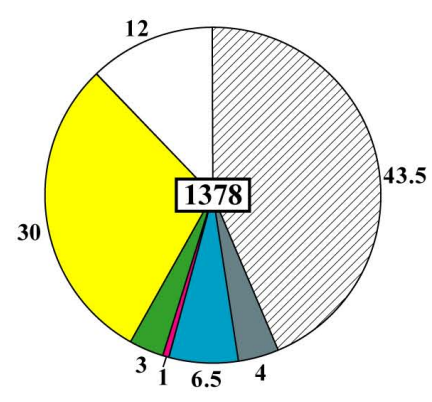

$16.5 \%$ species

5126 Density (No ind./100 $\mathrm{cm}^{2}$ )

Fig. 6. Relative abundances of the major species in the $>150 \mu \mathrm{m}$ (a) and the $63-150 \mu \mathrm{m}$ size fractions (b) at Station A for the four sampling periods.

the mouth; Goineau et al., 2011). Stations A and N were both characterised by a mixture of soil and plant-derived OM in all four sampling periods, and plotted close to the samples collected in October 2004 and September 2006 conditions. Consequently, no clear marine influence was recorded at our two stations, in none of the four sampling periods. It appears that variations in Chl- $a$ contents between sampling periods were mainly due to changes in the Rhône River regime (high/low discharge) and riverine phytoplankton dynamics which appears to bloom at the same time as marine phytoplankton (Harmelin-Vivien et al., 2008). At both stations, the accumulation of labile (i.e. bioavailable) Rhône-derived material at the river mouth and in the proximal prodelta, not necessarily linked to river phytoplankton blooms, led to an important sediment oxygen consumption, due to organic carbon mineralisation (high DOU, shallow OPD), during the four investigated periods (Table 3).

\subsection{Temporal dynamics of benthic foraminiferal faunas}

Foraminiferal datasets from ecological studies are usually established on the basis of one sample (i.e., core) per investigated station. Only few studies dealing with shelf environments (Buzas, 1968; Hohenegger et al., 1989, 1993; Buzas and Gibson, 1990; Silva et al., 1996; Swallow, 2000; Buzas et al., 2002; Morvan et al., 2006) have investigated the spatial dynamics of benthic foraminifera at a small spatial scale $(<1 \mathrm{~km})$. In these papers, small-scale (decimetric to decametric) spatial variability of benthic foraminiferal faunas exists and is generally explained by a patchy distribution of organic detritus at the seafloor. In our study area, unpublished data show that absolute abundances of major foraminiferal taxa at a single site may present a significantly patchy distribution at a decimetric scale. However, the variability of foraminiferal percentages (i.e. relative abundances) 
(a) Foraminiferal abundance D

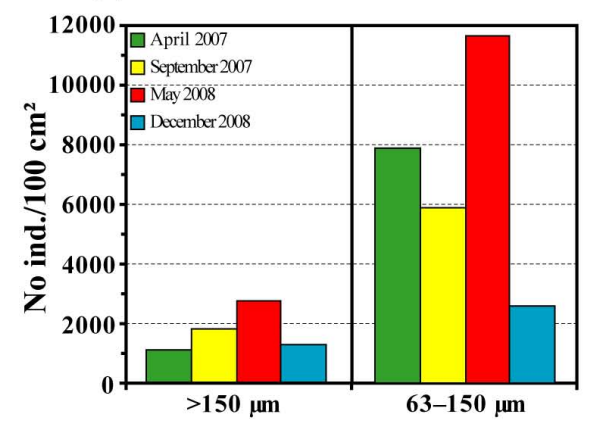

(c) Shannon index $\mathrm{H}$

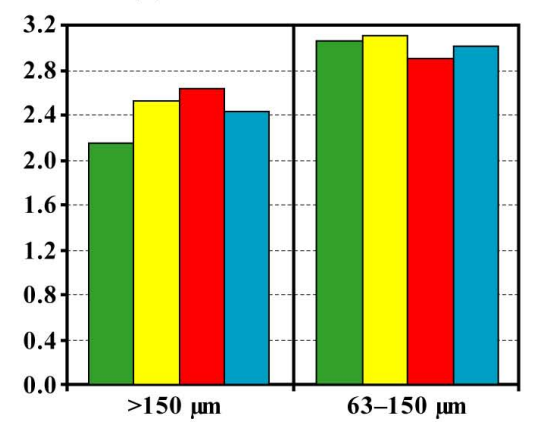

(b) Species richness $\mathrm{S}$

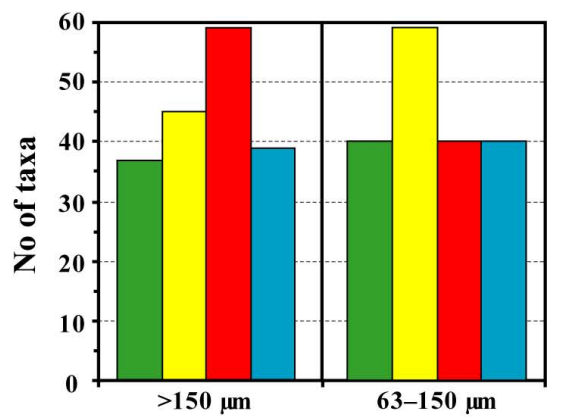

(d) Evenness index $\mathbf{E}$

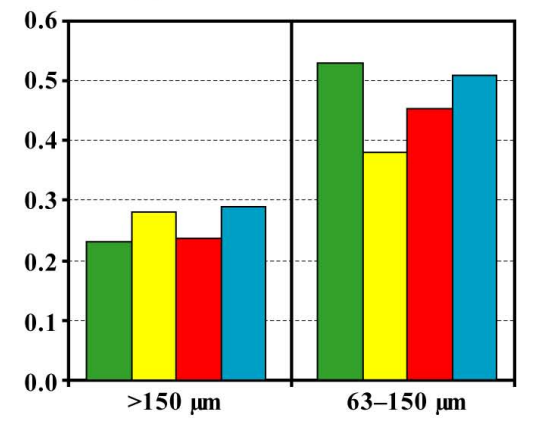

Fig. 7. Foraminiferal abundance D standardised for a surface area of $100 \mathrm{~cm}^{2}$ (core surface: $72 \mathrm{~cm}^{2}$; sediment depth: $0.5 \mathrm{~cm}$ for the $63-$ $150 \mu \mathrm{m}$ size fraction and $5 \mathrm{~cm}$ for the $>150 \mu \mathrm{m}$ size fraction) (a), species richness S (b), Shannon index $\mathrm{H}$ (c) and Evenness index E (d) of the total living foraminiferal faunas in the $>150 \mu \mathrm{m}$ and $63-150 \mu \mathrm{m}$ size fractions at Station $\mathrm{N}$ for the four sampling periods.

is not significant. Since our temporal survey of benthic foraminiferal faunas was performed with only one core per investigated site and per sampling period, the following discussion is based on percentage data of the major species.

Moreover, Mojtahid et al. (2010) studied the vertical distribution of benthic foraminiferal faunas living at 23 stations in the Rhône prodelta. Their results show the difficulty in this area to divide benthic foraminiferal microhabitats into shallow, intermediate and deep infaunal taxa. Indeed, most foraminifera live in the topmost centimetre of the sediment because of the shallow oxygen penetration depth measured in the whole prodelta $(<1 \mathrm{~cm})$. Moreover, the Rhône prodelta is characterised by important sediment deposition rates and organic carbon fluxes, leading to a deep sediment surface mixed layer in the whole prodelta (i.e. $\sim 7-10 \mathrm{~cm}$ depth; Miralles et al., 2005). Considering these dynamic conditions and the lack of clear vertical distribution patterns of benthic foraminiferal faunas (Mojtahid et al., 2010), microhabitats are not discussed in this study, except for Station A in May 2008 and in December 2008 when sampling was performed during/after flood events.

\subsubsection{Station A}

The foraminiferal faunas observed at Station A, dominated by Ammonia tepida, Bolivina dilatata, Eggerella scabra, Haynesina germanica, Leptohalysis scottii, Nonion fabum, Nonionella stella, Nonionella turgida, Psammosphaera fusca and Stainforthia fusiformis, are typical of river-dominated shelves (e.g. Jorissen, 1987; van der Zwaan and Jorissen, 1991; Barmawidjaja et al., 1992; Jorissen et al., 1992; Donnici and Serandrei Barbero, 2002; Diz et al., 2006; Diz and Francés, 2008; Frezza and Carboni, 2009), and especially of the Rhône prodelta (Mojtahid et al., 2009; Goineau et al., 2011).

In April 2007, sampling is performed during a low Rhône discharge and spring bloom conditions in the Gulf of Lions (SeaWifs images: "Ocean Colour" website, http://marine.jrc. ec.europa.eu/). The very rich foraminiferal faunas are dominated by Bolivina dilatata, Nonionella stella, Nonionella turgida, Stainforthia fusiformis and Leptohalysis scottii in the 63-150 $\mu \mathrm{m}$ size fraction, and Nonion fabum, Nonionella turgida, Eggerella scabra and Leptohalysis scottii in the $>150 \mu \mathrm{m}$ size fraction (Fig. 6). Both size fractions present well diversified faunas with a maximal biodiversity (Shannon index) and standing stocks in the $63-150 \mu \mathrm{m}$ size fraction (Fig. 5). In the Rhône prodelta, N. fabum seems to be adapted to a wide range of environments, thriving preferentially in 
(a) $>150 \mu \mathrm{m}$ size fraction
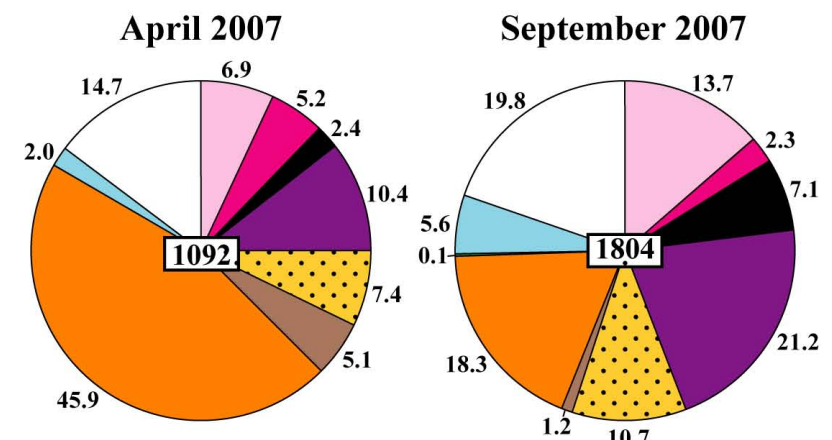

Nonion fab um

Nonionella turgida

Rectuvigerina phlegeri

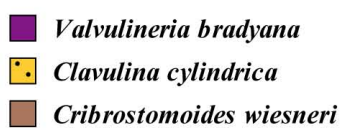

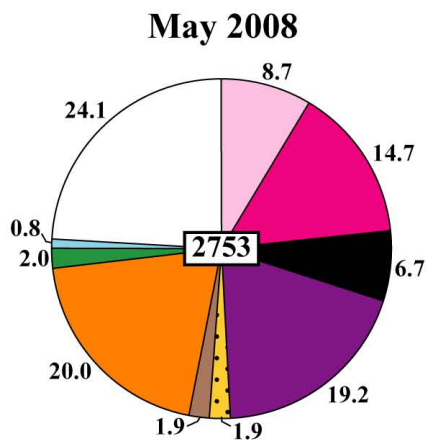

Eggerella scabra

Leptohalysis scottii

Nouria polymorphinoides
December 2008

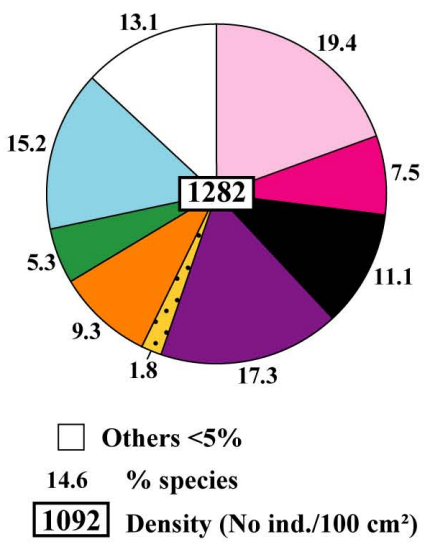

(b) $63-150 \mu \mathrm{m}$ size fraction
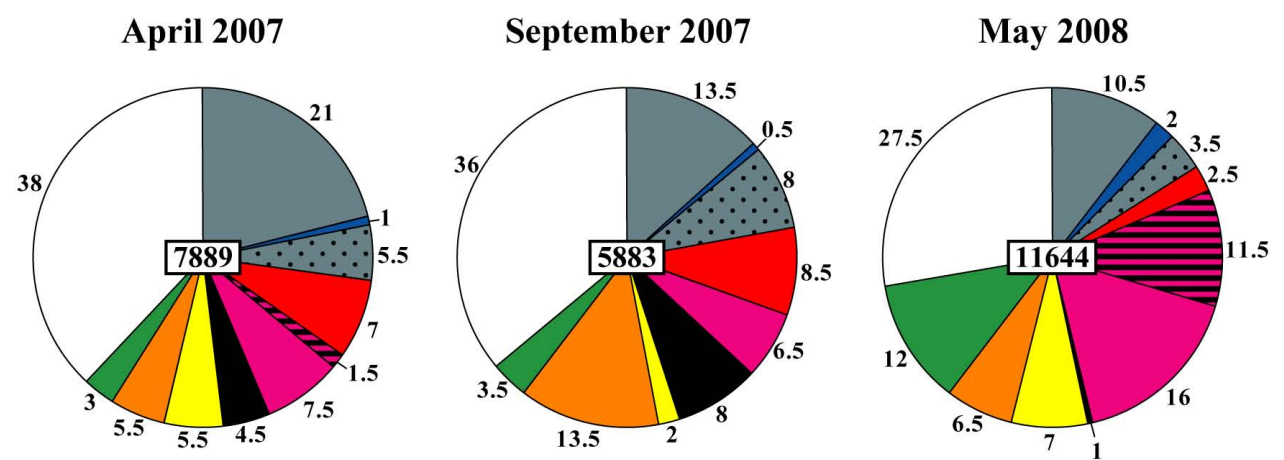

\section{December 2008}

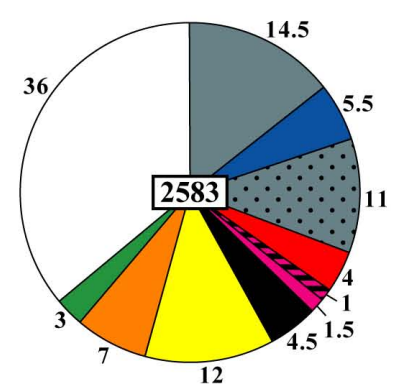

Bolivina dilatata

Bolivina seminuda

$\square$ Hopkinsina atlantica

$\square$ Rectuvigerina phlegeri
$\square$ Textularia porrecta
$\square$ Eggerella scabra

Leptohalysis scottii

Others $<5 \%$

Bolivina spathulata

Nonionella iridea
Nonionella turgida

Fig. 8. Relative abundances of the major species in the $>150 \mu \mathrm{m}$ (a) and the 63-150 $\mu \mathrm{m}$ size fractions (b) at Station $\mathrm{N}$ for the four sampling periods.

sediments enriched in both continental and more marine $\mathrm{OM}$ under the river plume (Mojtahid et al., 2009; Goineau et al., 2011). Bolivina dilatata, N. turgida and E. scabra are abundant in a restricted area close to the Rhône River mouth, receiving important amounts of continental OM (Mojtahid et al., 2009; Goineau et al., 2011). However, these species would also be able to feed on fresh phytodetritus inputs, especially diatoms (Hohenegger et al., 1993; Gustafsson and Nordberg, 2001; Diz et al., 2006; Diz and Francés, 2008; Duchemin et al., 2008; Hyams-Kaphzan et al., 2009). Bolivina dilatata is known to proliferate, due to an opportunistic behaviour after fresh phytodetritus inputs in river-influenced environments (Barmawidjaja et al., 1992; Jorissen et al., 1992; Duchemin et al., 2007, 2008). Therefore, its occurrence in April 2007 would suggest a recent deposition of fresh phytodetritus possibly originating from the river. This hypothesis is corroborated by the occurrence of $N$. stella, $N$. turgida and $S$. fusiformis which have also been reported in the Ría de Vigo (Spain) and in the Bay of Biscay responding to fresh OM inputs by enhanced reproduction (Gustafsson and Nordberg, 2001; Diz et al., 2006; Diz and Francés, 2008). At Station A, we observe specimens of $N$. turgida and L. scottii in both size fractions, showing the presence of both adult and juvenile forms, probably as a result of reproduction shortly before sampling. Stainforthia fusiformis has been observed close to the Rhône River mouth during late spring bloom conditions (June 2005; Mojtahid et al., 2009). It appears therefore that the above-mentioned group of taxa constitutes a highly reactive and diverse fauna responding to the eutrophic conditions in the vicinity of the Rhône River mouth, following riverine phytoplankton blooms. 


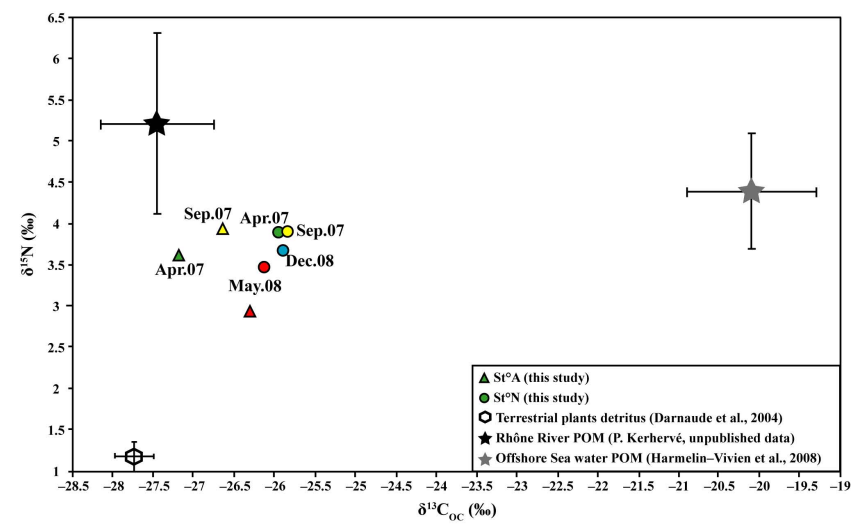

Fig. 9. Stable isotopic composition of the organic matter $\left(\delta^{13} \mathrm{C}_{\mathrm{OC}}\right.$ vs. $\left.\delta^{15} \mathrm{~N}\right)$ from the first half-centimetre of sediment at both Stations A and $\mathrm{N}$ (except for December 2008 at Station A; no available $\delta^{15} \mathrm{~N}$ value). The composition of three possible OC sources (Terrestrial plant detritus, Rhône River POM, and offshore seawater POM) are also plotted to illustrate the relative influence of each source. The Rhône River POM is the mean signature of the river between 2006 and 2008 (monthly sampling; Kerhervé et al., 2012).

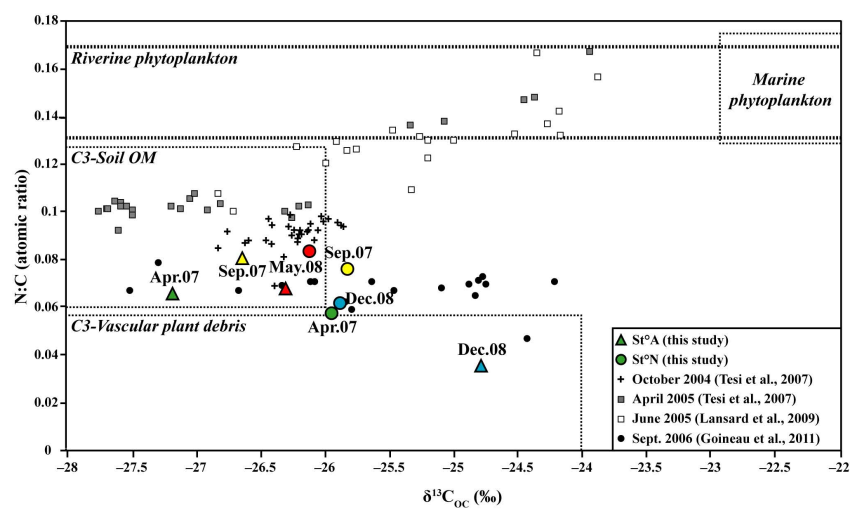

Fig. 10. Stable isotopic composition of the organic carbon $\left(\delta^{13} \mathrm{C}_{\mathrm{OM}}\right)$ vs. N:C atomic ratio for the first half-centimetre of sediment measured at Stations A and $\mathrm{N}$ during the four sampling periods. The four other databases represented were collected in September 2006 (Goineau et al., 2011), October 2004 and April 2005 (Tesi et al., 2007), and June 2005 (Lansard et al., 2009). The composition of four possible OC sources $\left(\mathrm{C}_{3}\right.$-vascular plant detritus, $\mathrm{C}_{3}$-soil $\mathrm{OM}$, marine and riverine phytoplankton detritus) is also plotted to illustrate the relative influence of each source. The $\mathrm{N}: \mathrm{C}$ ratio was used rather than the classical C:N ratio because the former are more robust statistically and behave linearly in a mixing model (Gordon and Goñi, 2003).

In September 2007, no major flood had occurred for the last 6 months, and the last significant phytoplankton bloom ended more than 3 months before sampling. The much poorer foraminiferal fauna is mainly composed of $B$. dilatata, L. scottii and Psammosphaera fusca in the $63-150 \mu \mathrm{m}$ size fraction, and Ammonia tepida, N. turgida, E. scabra and $L$. scottii in the larger size fraction (Fig. 6). Ammonia tepida is a very common taxon in shallow open marine environments, especially at the vicinity of river mouths (e.g. Jorissen, 1987, 1988; Donnici and Serandrei Barbero, 2002; Rossi and Vaiani, 2008; Frezza and Carboni, 2009; Goineau et al., 2011). Psammosphaera fusca is a monothalamous agglutinated taxon observed from deep-sea (Kaminski, 1985; Jones, 1988; Kaminski et al., 1995; Harloff and Mackensen, 1997) to shelf environments (Canadian fjord, Antarctic coast, Laptev Sea; Lukina, 2001; Gadzicki and Majewski, 2003; Vázquez Riveiros and Patterson, 2007). Psammosphaera fusca has been reported as a pioneer opportunistic species in high-energy environment (Kaminski, 1985; Kaminski et al., $1995)$. Thus, the dominance $(\sim 50 \%)$ of $P$. fusca in the 63$150 \mu \mathrm{m}$-sized fauna could suggest a possible physical disturbance of the benthic environment by moderate to strong currents. In parallel, the association of B. dilatata, $N$. turgida, E. scabra and L. scottii contributing to diverse $(\mathrm{H}>1.8)$ and relatively equilibrated faunas $(\mathrm{E} \approx 0.35)$ could be linked to the important amounts of labile organic compounds (lipids, THAA, Chl- $a$; Table 3) measured in the sediment. To summarise, the low-abundant but well-diversified fauna observed in September 2007 suggests an environment which is characterised by a larger proportion of bio-available organic matter, possibly disturbed by more or less high-energy conditions.

Sampling of Station A in May 2008 took place during very peculiar conditions. A major Rhône River flood characterised by very high SPM load (until $867 \mathrm{mg} \mathrm{l}^{-1} \mathrm{~d}^{-1}$; SORA Station data) started two days before sampling. A $3 \mathrm{~cm}$-thick flood deposit constituted by very light liquid mud $(\mathrm{D}(0.50)$ $=6.7-7.3 \mu \mathrm{m})$ was observed at the surface of all cores sampled at this station (Fig.3, Table 2). The huge accumulation rate induced by the flood led to a strong dilution of $\mathrm{OM}$ and much lower OC, labile organic compounds and Chl- $a$ contents (Fig. 4). These extreme conditions where probably responsible for the almost monospecific foraminiferal faunas, consituted by almost $100 \%$ of L. scottii in both size fractions (Fig. 6). In the $>150 \mu \mathrm{m}$ size fraction, L. scottii reached huge abundances of $\sim 7500$ ind. $/ 100 \mathrm{~cm}^{2}$, and the densities increased with sediment depth (Fig. 11a). This virtually monospecific $L$. scottii assemblage can be explained in two different ways: (1) the specimens present at the site or in surrounding areas before the flood responded to the disturbance induced by the flood deposit by an extremely fast reproduction (strongly opportunistic behaviour); (2) individuals were transported together with terrigeneous material from the Rhône River during the flood (allochthonous origin). The first scenario implies that massive reproduction had to take place in less than 2 days, the time-lapse between the beginning of the flood and sediment sampling. In culture experiments performed on sediments sampled in the northern Adriatic Sea near the Po outlet (32 $\mathrm{m}$ water depth), Ernst et al. (2002) showed that $L$. scottii could enlarge its population by $80 \%$ in the three weeks following a simulated physical disturbance consisting in a gentle mixing of the sediment. 
(a) May 2008

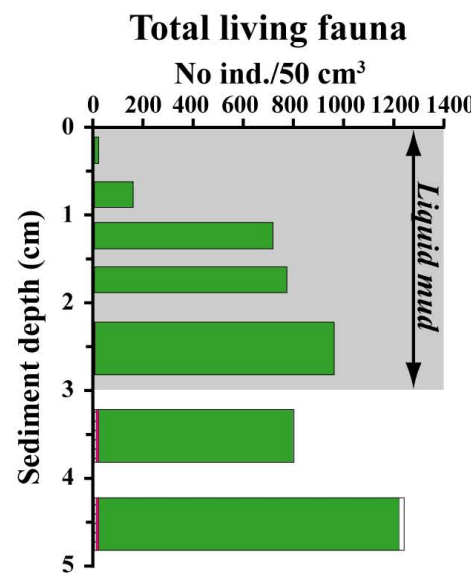

(b) December 2008

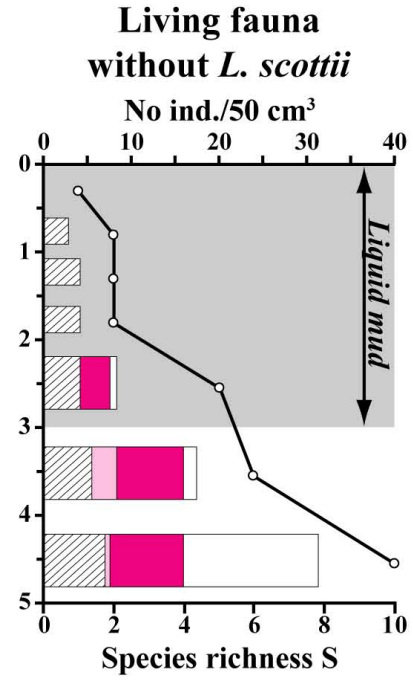

\section{Total living fauna}

No ind. $/ 50 \mathrm{~cm}^{3}$

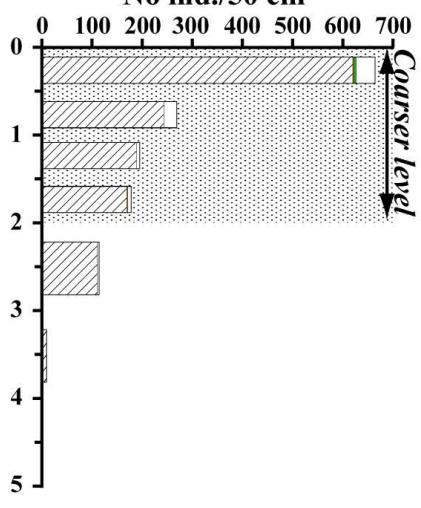

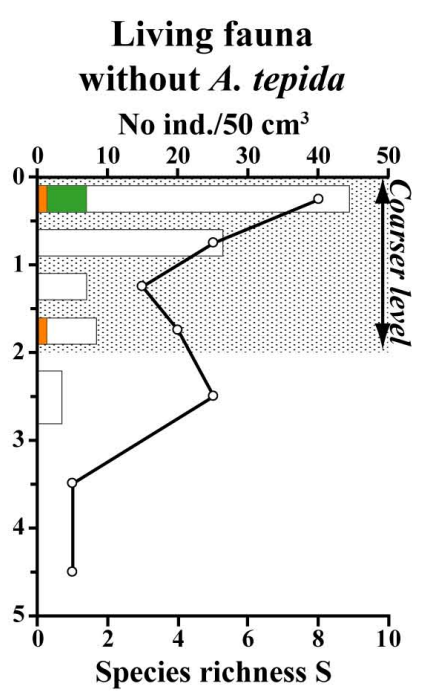

$\bigotimes$ Ammonia tepida $\square$ Nonion fabum

Nonionella turgida

Eggerella scabra

Leptohalysis scottii

Others $<5 \% \rightarrow$ Species richness $S$

Fig. 11. Vertical distribution of the major taxa at Station A in May 2008 (a) and December 2008 (b). On the right are represented the species richness $\mathrm{S}$ and the vertical distribution of the faunas without dominant taxa, i.e. without Leptohalysis scottii in May 2008 and without Ammonia tepida in December 2008.

It seems therefore unlikely that more than 7000 individuals $/ 100 \mathrm{~cm}^{2}$, most of them adults or pre-adults found in the $>150 \mu \mathrm{m}$ size fraction, were produced in only 2 days, in an environment impoverished in OM. The second assumption of an allochthonous origin of $L$. scottii would imply a massive transport from the continental part of the Rhône River to the proximal prodelta. L. scottii has earlier been reported from estuarine environments living in turbid and high-energy waters (Scott et al., 2005; Diz and Francés, 2008). Unfortunately, we have no data on the foraminiferal community living upstream from the Rhône River mouth even if the flexible and micaceous test of $L$. scottii might be an ecomorphological adaptation to colonise and thrive in high-energy (i.e. high-turbidity) environments. Thus, the hypothesis of an allochthonous origin of the thousands of individuals of $L$. scottii seems so most probable. This taxon is a very early recoloniser of a newly deposited sediment surface as earlier described in the Oslofjord where individuals of $L$. scottii rapidly immigrated from neighbouring environments to massively colonise newly deposited sediments (Hess et al., 2010). In parallel, a close inspection of foraminiferal census data reveals relatively high species richness under the flood deposit, i.e. under the former sediment-water interface, with few individuals of Nonion fabum, Nonionella turgida, Nonionella stella and 8 other additional taxa (Fig. 11a). The association of $N$. fabum, N. turgida and N. stella was already observed in April 2007, constituting $\sim 20 \%$ of the small-sized faunas and $\sim 31 \%$ of the $>150 \mu \mathrm{m}$ size fraction (Fig. 6).
Therefore, these three taxa likely belong to the pre-flood faunas. Sediment has not been eroded by the flood, and the former surface layer is still in place under the flood deposit.

In December 2008, Cathalot et al. (2010) showed at a station close to the river mouth $(45 \mathrm{~m}$ depth) that $\sim 10 \mathrm{~cm}$ of soft mud had been eroded by a flood occuring 3 weeks before sampling. This flood carried sediment rich in $\mathrm{OC}$ and plant debris. We assume that similar processes occurred at shallower sites, i.e. at Station A, likely removing also living foraminiferal faunas in place before the flood. At Station A, three weeks after this major disturbance, living benthic foraminifera are observed down to, at least, $4 \mathrm{~cm}$ depth (Fig. 11b). The newly-deposited flood layer, which consists in a $\sim 2 \mathrm{~cm}$-thick sandy level (Fig. 3, Table 2), is inhabited by $\sim 1500$ ind. $/ 50 \mathrm{~cm}^{3}$ of Ammonia tepida (multichambered calcareous species), $\sim 200$ ind. $150 \mathrm{~cm}^{3}$ of Psammosphaera fusca (single-chambered agglutinated taxon) but also specimens of Haynesina germanica (Figs. 6 and 11b). Haynesina germanica is a typical estuarine species, thriving in intertidal and subtidal areas (e.g. Alve and Murray, 1999; Debenay et al., 2000; Diz and Francés, 2008). It appears therefore that the association of A. tepida, H. german$i c a$ and $P$. fusca is indicative of a very high riverine influence. The flood recorded 3 weeks before ( $\mathrm{Q}$ until $\sim 4800 \mathrm{~m}^{3} \mathrm{~s}^{-1}$; SORA Station) may have significantly disturbed the benthic environment by the deposit of organic-rich terrigeneous material close to the river mouth (OC content $=6 \%$ d.w.; Cathalot et al., 2010). Since $H$. germanica is typical of 


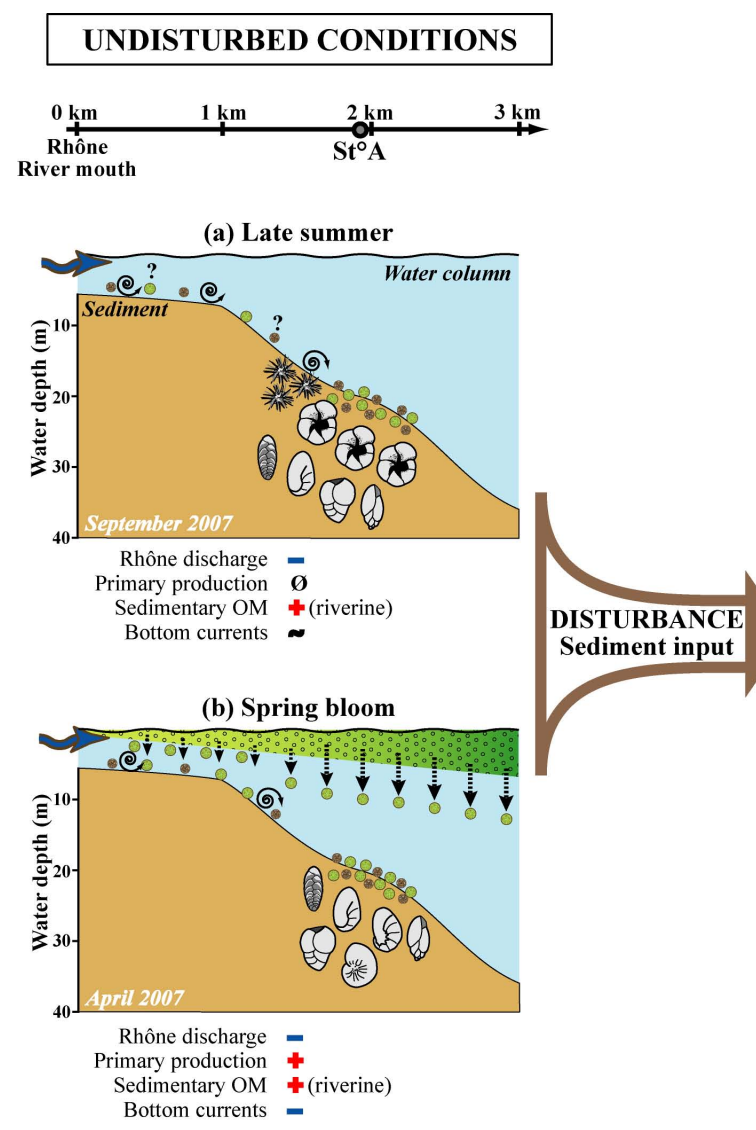

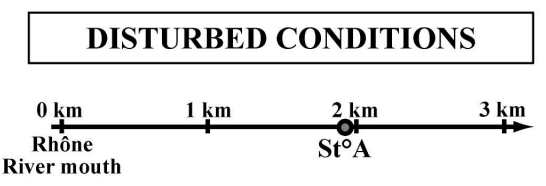

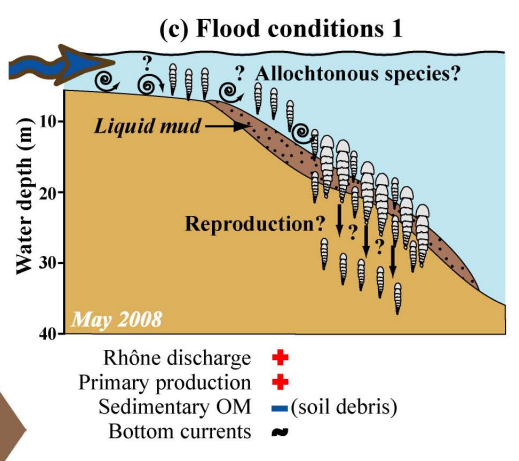

(d) Flood conditions 2

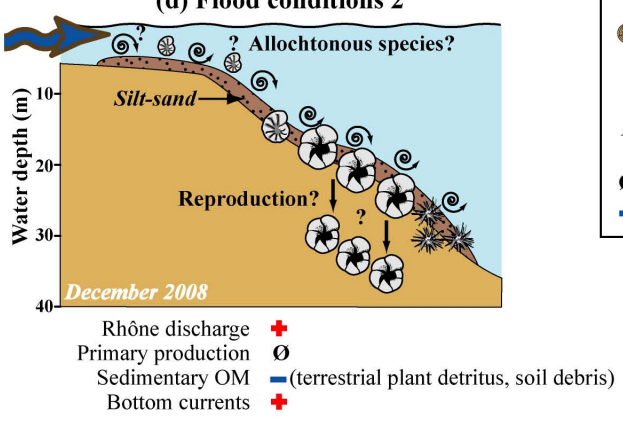

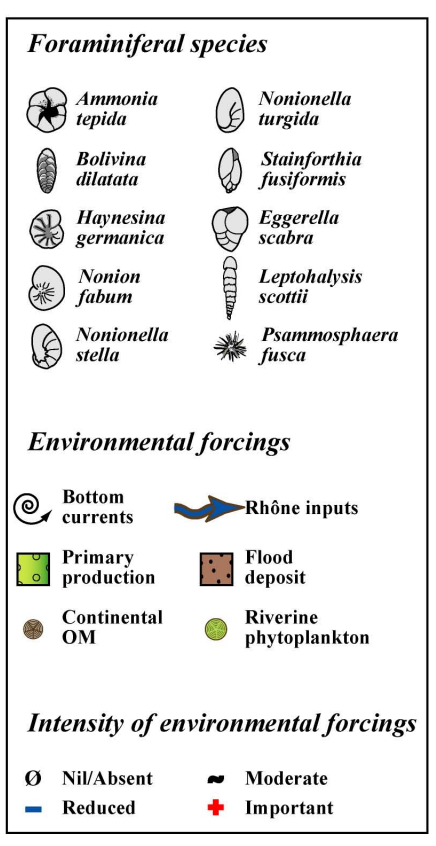

Fig. 12. Synthetic picture of the processes influencing the foraminiferal faunal composition during the four investigated periods at the shallowest Station A.

brackish water environments, it can be supposed that juvenile specimens of this taxon have been transported by the flood from habitats in the inner part of the Rhône River channel to our study site. At a slightly later stage, A. tepida and $P$. fusca may have colonised the newly deposited organic-rich flood deposit, profiting from their high tolerance for highenergy conditions. Numerous culture experiments in laboratory conditions have focused on reproduction and growth rates of foraminiferal species from shelf environment (e.g., Bradshaw, 1955, 1957, 1961; Goldstein and Moodley, 1993; Stouff et al., 1999; Barras et al., 2009). Their results show that reproduction rates of A. tepida and Bulimina marginata, two multi-chambered calcareous taxa, are constrained by sea water temperature, the quantity/quality of food supplies, but also the size of the starting pool of juveniles. For instance, Bradshaw $(1955,1957,1961)$ reported a growth rate for $A$. tepida ranging from 4 to $84 \mu \mathrm{m} / 10$ days. A more recent study by Stouff et al. (1999) reported that already calcified juveniles of A. tepida could form a third chamber within $24 \mathrm{~h}$ after their release from the reproduction cyst, and a fourth chamber within a few hours. In our study, $\sim 30 \%$ of the observed
A. tepida were juvenile specimens (between 63 and $150 \mu \mathrm{m}$ ). According to culture experiments results presented above, it seems possible that this juvenile population was produced during the three weeks ( $\sim 20$ days) between the flood and time of sampling. This assumption can also be made for the pioneer opportunistic species $P$. fusca. Since this species produces only one chamber constituted by lithic elements, its reproduction and growth rates may be relatively fast (Kaminski, 1985; Kaminski et al., 1995; Fontanier et al., 2008). All these observations traduce the dynamic and unstable conditions, presumaly linked to the Rhône regime, prevailing at this shallow site at this sampling period. Nonetheless, in the Rhône prodelta, wave-generated currents can also disturb the benthic environment down to $30 \mathrm{~m}$ water depth, notably during the autumn and winter seasons when onshore winds generate high-energy waves (e.g. LCHF, 1976; Migniot and Viguier, 1980; Suanez, 1997; Sabatier and Suanez, 2003). Therefore, in Dcember 2008, wind/wave-related bottom currents may also have played a key role in the sediment erosion/deposition processes assumed at the shallow Station A (24 $\mathrm{m}$ depth). 
To synthesise, foraminiferal faunas observed at this shallow Station A were obviously influenced by the Rhône River in some way during all four periods (Fig. 12). Sedimentary disturbance appears to be periodically disturbing the benthic environment. Stable environmental conditions, without major sediment input, which prevailed in April and September 2007 allowed the establishment of diverse and equilibrated faunas (Fig. 12a-b). The availability of fresh OM and the hydrodynamic conditions above the sea floor were the main factors influencing foraminiferal faunal composition. Conversely, highly unstable conditions with massive sediment input characterise the environment in May and December 2008 (Fig. 12c-d). The particular conditions led to the presence of faunas typical for the early stages of ecosystem colonisation. In these faunas, the foraminiferal composition appears to depend on the time lapse since the last flood deposit, and on the OM content of the recently deposited sediments. A few days after such a massive sediment input (May 2008), an extremely rich monospecific assemblage of pioneer species already inhabited the newly deposited flood layer impoverished in labile OM. Conversely, an input of OM enriched sediments in December 2008 led to the observation, a few weeks later, of a more advanced colonisation stage. In both cases, foraminiferal faunas responded with an opportunistic strategy to the deposition of a thick layer of new sediment (Leptohalysis scottii, May 2008) and/or to the high amounts of OM supplied by the river flood (Ammonia tepida, December 2008).

\subsubsection{Station $N$}

At Station N, environmental conditions are much less contrasted than at the shallower Station A (see Sect. 4.1.). Foraminiferal faunas of both size fractions were diverse (Shannon index $\mathrm{H}>2$ ) and relatively equilibrated $(\mathrm{E}>0.2)$ during the four investigated periods, depicting the absence of opportunistic behaviour and/or recolonisation phenomena. Four taxa were abundant in all assemblages: Bolivina dilatata, Eggerella scabra, Nonion fabum and Valvulineria bradyana. These four taxa are common in the Rhône prodeltaic area, present in sediments close to the Rhône River mouth with important continental OM supplies (Station A, see above), but also at sites more offshore, under the Rhône River plume (Mojtahid et al., 2009; Goineau et al., 2011). Bolivina dilatata is described as an ubiquitous taxon adapted to a wide range of environmental conditions in the Ría de Vigo (Spain) and in the Bay of Biscay (Diz and Francés, 2008; Duchemin et al., 2008), also able to respond to fresh phytodetritus input (Barmawidjaja et al., 1992; Jorissen et al., 1992; Duchemin et al., 2007, 2008).

As for Station A, sampling in April 2007 took place during the early spring bloom and under low Rhône discharge conditions. At Station N, these conditions led to relatively high OC $(1.42 \%$ d.w. $)$ and Chl- $a$ contents in surficial sediments (2.57 $\mu \mathrm{g} \mathrm{g}^{-1}$; Table 3). The small-sized $(63-150 \mu \mathrm{m})$ benthic foraminiferal fauna of the topmost $0.5 \mathrm{~cm}$ was very abundant and highly diverse compared to the $>150 \mu \mathrm{m}$ size fraction of the upper $5 \mathrm{~cm}$ (Fig. 8). These faunas were characterised by high relative abundances of Clavulina cylindrica, Cribrostomoides wiesneri and Hopkinsina atlantica. As suggested for Station A at the same sampling period, the very high contribution of Eggerella scabra in the $>150 \mu \mathrm{m}$-sized fauna ( $>40 \%$ ) would be due to its ability to respond to fresh phytodetritus inputs. Clavulina cylindrica was considered typical of eutrophic conditions on the continental shelf of the Bay of Biscay (Fontanier et al., 2002). Hopkinsina atlantica has been described in river-influenced shelves (Barmawidjaja et al., 1992; Jorissen et al., 1992; Diz and Francés, 2008; Mojtahid et al., 2009), where it was usually considered as an opportunistic taxon responding to fresh OM input (Ernst et al., 2002; Duijnstee et al., 2005). When considering the moderate enrichment in Chl- $a$ of the top half centimetre of sediment at this period, this association of foraminiferal species would have benefited from an input of fresh phytodetritus, such as has been suggested for the shallower Station A at the same period.

In September 2007, high percentages of Bolivina spathulata, C. cylindrica, H. atlantica, Rectuvigerina phlegeri, and especially of Nouria polymorphinoides were noticed (Fig. 8) Goineau et al. (2011) reported N. polymorphinoides during another sampling period (September 2006) in coarse sediments from the coast west of the Rhône River mouth, close to Station N. According to Sabatier and Suanez (2003), this area is submitted to strong bottom currents. At Station A, the foraminiferal faunas observed in September 2007 suggested possibly high-energy conditions. Therefore, the contribution of $N$. polymorphinoides in September 2007 could indicate the possible action of bottom currents as at Station A. These currents could possibly have transported living individuals of $N$. polymorphinoides from sandy coastal sediments to our Station N.

In May 2008, Station N was sampled 3 days after the beginning of a major flood carrying important amounts of organic and inorganic terrestrial material close to the river mouth. However, contrary to Station A, no flood deposit was observed at the surface of any of the sampled cores. Consequently, we assumed that Station $\mathrm{N}$ had not been impacted by the deposits of terrigenous material. Therefore, just as in April 2007, the late spring bloom conditions prevailing in the Gulf of Lions at the time of sampling (SeaWifs images) would have been the main controlling parameter at the study site. In May 2008, the foraminiferal faunas were characterised by a high contribution of Nonionella iridea, Nonionella turgida and Leptohalysis scottii in the 63$150 \mu \mathrm{m}$ size fraction, and of $N$. turgida in the large-sized fauna (Fig. 8). Gustafsson and Nordberg (2001) demonstrated that $N$. turgida could reproduce and grow from juvenile to adult form in less than 1 month after a fresh OM deposit. In the present study, high abundances of $N$. turgida in both size fractions $(\sim 15 \%)$, together with the occurrence 
of $N$. iridea, which was rare to totally absent during the three other seasons, suggest the recent input of fresh $\mathrm{OM}$ at the study site (Gooday, 1986; Mackensen et al., 1990; Gooday and Hughes, 2002; Duchemin et al., 2007, 2008). In shelf environments, local accumulation of food particles in decimetric depressions can favour the growth of the most opportunistic taxa (e.g. N. turgida) by enhanced reproduction and growth (Buzas, 1968; Hohenegger et al., 1989, 1993; Buzas and Gibson, 1990; Silva et al., 1996; Swallow, 2000; Buzas et al., 2002; Morvan et al., 2006). In May 2008, surficial sediments were enriched in fresher OM $(\mathrm{C}: \mathrm{N}=12$, labile $\mathrm{OM}=27.0 \%$ OC; Table 3) than in April 2007 under similar spring bloom conditions $(\mathrm{C}: \mathrm{N}=17.4$, labile $\mathrm{OM}=19.2 \%$ OC; Table 3).

In December 2008, sediment samples were recovered 1 month after a major Rhône flood. The high amounts of fresh water and organic-rich suspended material $\left(\mathrm{Q}>2000 \mathrm{~m}^{3} \mathrm{~s}^{-1}\right.$ and $\mathrm{SPM}_{\text {mean }} \sim 172 \mathrm{mg} \mathrm{l}^{-1} \mathrm{~d}^{-1}$ during 12 days) carried to the Gulf of Lions during this flood would explain the high contents in labile OM measured in the surficial sediments of Station N (Table 3). In the foraminiferal faunas, B. spathulata, R. phlegeri and N. polymorphinoides were abundant, but a high contribution of Bolivina seminuda and Textularia porrecta was also observed in the $63-150 \mu \mathrm{m}$ size fraction (Fig. 8). The occurrence of $N$. polymorphinoides would plead for a noticeable action of bottom currents as in September 2007. In the Mediterranean Sea, the association of $B$. seminuda and $B$. spathulata has frequently been reported in meso- to eutrophic environments (e.g. Barmawidjaja et al., 1992; Jorissen et al., 1995; De Rijk et al., 2000; Schmiedl et al., 2000; Duijnstee, 2001). In the Bay of Biscay, this association of bolivinid species characterised spring bloom conditions after phytodetritus input (Fontanier et al., 2003; Langezaal et al., 2006). Therefore, the occurrence of these species is coherent with the high labile OM content of the sediment resulting from a recent input of riverine organic material deposited by a major Rhône River flood.

To summarise, slight variations noticed in the foraminiferal faunas of Station $\mathrm{N}$ would be linked either to fresh OM supplies from surface primary production and/or to the Rhône River regime. In April 2007 and May 2008, spring bloom conditions allowed the growth of species able to feed on fresh phytodetritus (e.g. Clavulina cylindrica, Hopkinsina atlantica, Nonionella iridea, Nonionella turgida). In September 2007 and December 2008, the establishment of the taxon Nouria polymorphinoides was indicative of a potential disturbance of the benthic environment by bottom currents. The additional input of riverine organic matter after a major flood in December 2008 was beneficial for taxa visibly able to thrive in environments submitted to a noticeable riverine influence (e.g. Bolivina seminuda, Bolivina spathulata, Textularia porrecta). Despite these putative environmental forcings, the recurrent occurrence of the four same taxa (i.e. Bolivina dilatata, Eggerella scabra, Nonion fabum, Valvulineria bradyana) in relatively high abundances at any period in diverse and equilibrated faunas depicts the relatively stable state of the environment at this site.

\section{Conclusions}

Sampling sediments from the Rhône prodelta in April 2007, September 2007, May 2008 and December 2008 permitted us to observe foraminiferal faunas under a wide range of environmental conditions. Foraminiferal communities were able to respond extremely quickly (days to weeks) to strong variations in organic supplies and riverine discharge, especially close to the river mouth (Station A). This response was noticeable but significantly reduced $\sim 5 \mathrm{~km}$ off the mouth (Station $\mathrm{N}$ ), probably due to a reduced impact of riverine input out of the proximal prodeltaic area.

Major disturbance of the benthic environment induced by massive sediment deposits at the shallowest Station A after Rhône River floods allowed the development of opportunistic species. Two days after a major flood event, thousands of individuals of Leptohalysis scottii were observed in newly deposited flood sediment, constituting an assemblage of very early recolonisers. A few weeks after another major flood (December 2008), typical species of river-dominated shelves (Ammonia tepida) and high-energy environments (Psammosphaera fusca) benefited from the high amounts of continental organic matter supplied by the flood. More stable conditions (i.e. no sediment deposit) allowed the growth of diverse and quite equilibrated faunas. Under the eutrophic conditions resulting from the spring phytoplankton bloom (April 2007), abundant and diverse fauna were composed of species feeding on fresh phytodetritus (e.g. Bolivina dilatata, Nonionella stella, Stainforthia fusiformis). Also in September 2007, diverse faunas were observed despite the oligotrophic conditions in surface water and/or the assumed high-energy conditions prevailing above the sea floor. At the farther station $\mathrm{N}$, Clavulina cylindrica, Hopkinsina atlantica, Nonionella iridea and Nonionella turgida are indicative of fresh OM input during eutrophic spring bloom conditions (April 2007, May 2008). On the contrary, the occurrence of Nouria polymorphinoides under oligotrophic conditions (September 2007, December 2008) was indicative of a benthic environment potentially disturbed by bottom currents.

Now, the question would be to know whether these rapid faunal changes are preserved and still treacable in the fossil faunas. Such knowledge would be particularly useful for paleo-environmental reconstructions, in the Rhône prodelta and in comparable shallow-water environments, especially to highlight abrupt events such as major floods. 


\section{Appendix A}

\section{Taxonomic reference list for major benthic} foraminiferal taxa

Ammonia tepida $($ Cushman $)=$ Rotalia beccarii Linnaeus var. tepida Cushman, 1926; in Jorissen, 1988, Plate 2, Fig. 8a-b (as Ammonia parkinsoniana f. tepida)

Bolivina dilatata (Reuss) = Brizalina dilatata Reuss, 1850; in Colom, 1974, Fig. 18j-n

Bolivina seminuda Cushman, 1911; in Mojtahid et al., 2008, Plate 1, Fig. 5

Bolivina spathulata (Williamson = Textularia variabilis Williamson var. spathulata Williamson, 1858; in Jorissen, 1988, Plate 1, Fig. 5

Clavulina cylindrica d'Orbigny, 1952; in Jones, 1994, Plate 44, Figs. 19-24

Cribrostomoides wiesneri (Parr) = Labrospira wiesneri Parr, 1950; in Jones, 1994, Plate 40, Figs. 14-15

Eggerella scabra (Williamson) = Bulimina scabra Williamson, 1858; in Jones, 1994, Plate 47, Figs. 15-17

Haynesina germanica (Ehrenberg) = Nonionina germanica Ehrenberg, 1840; in Diz and Francès, 2008, Plate II, Fig. 5

Hopkinsina atlantica $($ Cushman $)=$ Hopkinsina pacifica Cushman var. atlantica Cushman, 1944; in Diz and Francès, 2008, Plate II, Fig. 8

Leptohalysis scottii (Chaster) = Reophax scottii Chaster, 1892; in Sgarella and Montcharmont Zei, 1993, Plate 2, Fig. 5

Nonion fabum (Fichtel and Moll) = Nautilus faba Fitchel and Moll, 1798; in Jones, 1994, Plate 109, Figs. 12-13

Nonionella iridea Heron-Allen and Earland, 1932; in "Discovery" Rept., v. 4, p. 438, Plate 16, Figs. 14-16

Nonionella stella Cushman and Moyer, 1930; in Diz and Francès, 2008, Plate 2, Fig. 6

Nonionella turgida (Williamson) = Rotalina turgida Williamson, 1858; in Jorissen, 1988, Plate 4, Figs. 11-13

Nouria polymorphinoides Heron-Allen and Earland, 1914; in Barmawidjaja et al., 1992, Plate 4, Fig. 4

Psammosphaera fusca Schulze, 1875; in Höglund, 1947, Plate 4, Figs. 9-10

Rectuvigerina phlegeri Le Calvez, 1959; in Schiebel, 1992, Plate 3, Fig. 10a-d

Stainforthia fusiformis (Williamson) = Bulimina pupoides d'Orbigny var. fusiformis Williamson, 1858; in Gooday andAlve, 2001, Plate 3, Figs. A-B-C

Textularia porrecta (Brady) = Textularia agglutinans d'Orbigny var. porrecta Brady, 1884; in Rept. Challenger Expedition, London, England, p. 364, Plate 43, Fig. 4

Valvulineria bradyana (Fornasini) = Discorbina bradyana Fornasini, 1900; in Jorissen, 1988, Plate 4, Figs. 1-2
Supplementary material related to this article is available online at: http://www.biogeosciences.net/9/1367/2012/ bg-9-1367-2012-supplement.pdf.

Acknowledgements. We would like to thank the crews and the captain of the R/V Téthys II (CNRS-INSU) during the RiOMar, RIOTECH, CHACCRA-bent 1 and CHACCRA-bent 2 campaigns, as well as all CHACCRA colleagues who provided us with precious environmental data. We acknowledge technical staff for their support at sea and in the laboratory: M. Gaultier, S. Terrien, M. Desmalades, K. Escoubeyrou, B. Rivière and G. Jeanty. We are also grateful to anonymous reviewers for their thorough and helpful comments which helped to improve our manuscript. This work was supported by the French National Research Agency, program "Vulnérabilités: Milieux et climat", under the grant no. ANR-06-VULN-001 to the CHACCRA project (Climate and Human-induced Alterations in Carbon Cycling at the River-seA connection) and by the Regional Council of Pays de la Loire.

Edited by: O. Radakovitch

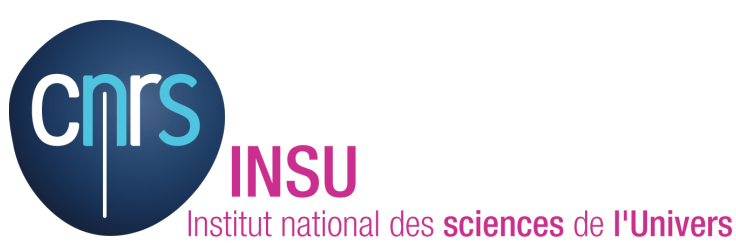

The publication of this article is financed by CNRS-INSU.

\section{References}

Alve, E., and Murray, J. W.: Marginal marine environments of the Skagerrak and Kattegat: a baseline study of living (stained) benthic foraminiferal ecology, Palaeogeogr. Palaeocl., 146, 171193, 1999.

Barmawidjaja, D. M., Jorissen, F. J., Puskaric, S., and Van Der Zwaan, G. J.: Microhabitat selection by benthic foraminifera in the northern Adriatic Sea, J. Foramin. Res., 22, 297-317, 1992.

Barras, C., Geslin, E., Duplessy, J.-C., and Jorissen, F. J.: Reproduction and growth of the deep-sea benthic foraminifer Bulimina marginata under different laboratory conditions, J. Foramin. Res., 39, 155-165, 2009.

Berné, S., and Gorini, C.: The Gulf of Lions: An overview of recent studies within the French "Margins" programme, Mar. Petrol. Geol., 22, 691-693, 2005.

Bernhard, J. M.: Postmortem vital staining in benthic foraminifera: duration and importance in population and distributional studies, J. Foramin. Res., 18, 143-146, 1988.

Bernhard, J. M.: Distinguishing live from dead foraminifera: Methods review and proper applications, Micropaleontology, 46, 38 46, 2000.

Béthoux, J.-P., and Prieur, L.: Hydrologie et circulation en Méditerranée Nord-Occidentale, Pétrole et techniques 229, 25 34, 1983. 
Bosc, E., Bricaud, A., and Antoine, D.: Seasonal and interannual variability in algal biomass and primary production in the Mediterranean Sea, as derived from 4 years of SeaWifs observations, Global Biogeochem. Cy., 18, 1-17, 2004.

Bourgeois, S., Pruski, A. M., Sun, M.-Y., Buscail, R., Lantoine, F., Vétion, G., Rivière, B., and Charles, F.: Distribution and lability of land-derived organic matter in the surface sediments of the Rhône prodelta and the adjacent shelf (Mediterranean sea, FRANCE): a multi proxy study, Biogeosciences, 8, 3107-3125, 2011, http://www.biogeosciences.net/8/3107/2011/.

Bradshaw, J. S.: Preliminary laboratory experiments on ecology of foraminiferal populations, Micropaleontology, 1, 351-358, 1955.

Bradshaw, J. S.: Laboratory studies on the rate of growth of the foraminifer, "Streblus beccarii (Linné) var. tepida (Cushman)", Journal of Paleontology, 31, 1138-1147, 1957.

Bradshaw, J. S.: Laboratory experiments on the ecology of foraminifera, Contributions from the Cushman Foundation for Foraminiferal Research, 12, 87-106, 1961.

Buzas, M. A.: On the spatial distribution of foraminifera, Contribution from the Cushman Foundation for Foraminiferal Research, $19,1-11,1968$.

Buzas, M. A., and Gibson, T. G.: Spatial distribution of Miocene foraminifera at Calvert Cliffs, Maryland, Smithsonian Contributions to Paleobiology, 68, 1-35, 1990.

Buzas, M. A., Hayek, L. A. C., Reed, S. A., and Jett, J. A.: Foraminiferal densities over five years in the Indian River Lagoon, Florida: A model of pulsating patches, J. Foramin. Res., 32, 68-93, 2002.

Calmet, D., and Fernandez, J.-M.: Caesium distribution in northwest Mediterranean seawater, suspended particles and sediments, Cont. Shelf Res., 10, 895-913, 1990.

Cathalot, C., Rabouille, C., Pastor, L., Deflandre, B., Viollier, E., Buscail, R., Grémare, A., Treignier, C., and Pruski, A.: Temporal variability of carbon recycling in coastal sediments influenced by rivers: assessing the impact of flood inputs in the Rhône River prodelta, Biogeosciences, 7, 1187-1205, 2010, http://www.biogeosciences.net/7/1187/2010/.

Charmasson, S., Radakovitch, O., Arnaud, M., Bouisset, P., and Pruchon, A.-S.: Long-core profiles of ${ }^{137} \mathrm{Cs},{ }^{134} \mathrm{Cs},{ }^{60} \mathrm{Co}$ and ${ }^{210} \mathrm{~Pb}$ in sediment near the Rhône River (Northwestern Mediterranean Sea), Estuaries Coasts, 21, 367-378, 1998.

Corliss, B. H., and Emerson, S.: Distribution of Rose Bengal stained deep-sea benthic foraminifera from the Nova Scotia continental margin and Gulf of Maine, Deep Sea Res., 37, 381-400, 1990.

Dagg, M. J., and Breed, G. A.: Biological effects of Mississippi River nitrogen on the northern gulf of Mexico-a review and synthesis, J. Marine Syst., 43, 133-152, 2003.

Darnaude, A., Salen-Picard, C., Polunin, N. C., and HarmelinVivien, M.: Trophodynamic linkage between river runoff and coastal fishery yield elucidated by stable isotope data in the Gulf of Lions (NW Mediterranean), Oecologia, 138, 325-332, 2004.

De Rijk, S., Jorissen, F. J., Rohling, E. J., and Troelstra, S. R.: Organic flux control on bathymetric zonation of Mediterranean benthic foraminifera, Mar. Micropaleontol., 40, 151-166, 2000.

Debenay, J.-P., Guillou, J.-J., Redois, F., and Geslin, E.: Distributional trends of foraminiferal assemblages in paralic
environments-A base for using foraminifera as bioindicators, in: Environmental micropaleontology, edited by: Martin, R. E., Kluwer Academic/Plenum Publishers, New York, 39-67, 2000.

Diaz, F.: Evolution saisonnière de la production primaire et des processus d'assimilation-régénération de l'azote dans le Golfe du Lion. Estimation d'un bilan de carbone. Approches in situ et modélisation, PhD Thesis, Aix-Marseille II University, 351 pp., 2000.

Diz, P., Francés, G., and Roson, G.: Effects of contrasting upwelling-downwelling on benthic foraminiferal distribution in the Ria de Vigo (NW Spain), J. Marine Syst., 60, 1-18, 2006.

Diz, P., and Francés, G.: Distribution of live benthic foraminifera in the Ría de Vigo (NW Spain), Mar. Micropaleontol., 66, 165-191, 2008.

Donnici, S., and Serandrei Barbero, R.: The benthic foraminiferal communities of the northern Adriatic continental shelf, Mar. Micropaleontol., 44, 93-123, 2002.

Duchemin, G., Fontanier, C., Jorissen, F. J., Barras, C., and Griveaud, C.: Living small-sized $(63-150 \mu \mathrm{m})$ foraminifera from mid-shelf to mid-slope environments in the Bay of Biscay, J. Foramin. Res., 37, 12-32, 2007.

Duchemin, G., Jorissen, F. J., Le Loc'h, F., Andrieux-Loyer, F., Hily, C., and Thouzeau, G.: Seasonal variability of living benthic foraminifera from the outer continental shelf of the Bay of Biscay, J. Sea Res., 59, 297-319, 2008.

Duijnstee, I. A. P.: Experimental ecology of foraminifera: towards better quantitative paleoecological reconstructions, $\mathrm{PhD}$ Thesis, Nijmegen and Utrecht Universities, 149 pp., 2001.

Duijnstee, I. A. P., de Nooijer, L. J., Ernst, S. R., and van der Zwaan, G. J.: Population dynamics of benthic shallow-water foraminifera: effects of a simulated marine snow event, Mar. Ecol. Prog. Ser., 285, 29-42, 2005.

Durrieu de Madron, X., Abassi, A., Heussner, S., Monaco, A., Aloisi, J. C., Radakovitch, O., Giresse, P., Buscail, R., and Kerherve, P.: Particulate matter and organic carbon budgets for the Gulf of Lions (NW Mediterranean), Oceanol. Acta, 23, 717-730, 2000.

Durrieu de Madron, X., Denis, L., Diaz, F., Garcia, N., Guieu, C., Grenz, C., Loÿe-Pilot, M.-D., Ludwig, W., Moutin, T., Raimbault, P., and Ridame, C.: Nutrients and carbon budgets for the Gulf of Lion during the Moogli cruises, Oceanol. Acta, 26, 421433, 2003.

Eisma, D.: Suspended matter in the aquatic environment, edited by: Springer, Berlin, New York, 315 pp., 1993.

Ernst, S., Duijnstee, I., and van der Zwaan, B.: The dynamics of the benthic foraminiferal microhabitat: recovery after experimental disturbance, Mar. Micropaleontol., 46, 343-361, 2002.

Fontanier, C., Jorissen, F. J., Licari, L., Alexandre, A., Anschutz, P., and Carbonel, P.: Live benthic foraminiferal faunas from the Bay of Biscay: faunal density, composition, and microhabitats, Deep Sea Res. Pt I, 49, 751-785, 2002.

Fontanier, C., Jorissen, F. J., Chaillou, G., David, C., Anschutz, P., and Lafon, V.: Seasonal and interannual variability of benthic foraminiferal faunas at $550 \mathrm{~m}$ depth in the Bay of Biscay, Deep Sea Res. Pt I, 50, 457-494, 2003.

Fontanier, C., Jorissen, F. J., Lansard, B., Mouret, A., Buscail, R., Schmidt, S., Kerhervé, P., Buron, F., Zaragosi, S., Hunault, G., Ernoult, E., Artero, C., Anschutz, P., and Rabouille, C.: Live foraminifera from the open slope between Grand Rhône and Pe- 
tit Rhône Canyons (Gulf of Lions, NW Mediterranean), Deep Sea Research Part I: Oceanographic Research Papers, 55, 15321553, 2008.

Frezza, V., and Carboni, M. G.: Distribution of recent foraminiferal assemblages near the Ombrone River mouth (Northern Tyrrhenian Sea, Italy), Rev. Micropaleontol., 52, 43-66, 2009.

Gadzicki, A., and Majewski, W.: Recent foraminifera from Goulden Cove of King George Island, Antarctica, Pol. Polar Res., 24, 3-12, 2003.

Goineau, A., Fontanier, C., Jorissen, F. J., Lansard, B., Buscail, R., Mouret, A., Kerhervé, P., Zaragosi, S., Ernoult, E., Artéro, C., Anschutz, P., Metzger, E., and Rabouille, C.: Live (stained) benthic foraminifera from the Rhône prodelta (Gulf of Lion, NW Mediterranean): Environmental controls on a river-dominated shelf, J. Sea Res., 65, 58-75, 2011.

Goldstein, S. T., and Moodley, L.: Gametogenesis and the life cycle of the foraminifer Ammonia beccarii (Linne) forma tepida (Cushman), J. Foramin. Res., 23, 213-220, 1993.

Gooday, A. J.: Meiofaunal foraminiferans from the bathyal Porcupine Seabight (northeast Atlantic): size structure, standing stock, taxonomy composition, species diversity and vertical distribution in the sediment, Deep Sea Res., 33, 1345-1373, 1986.

Gooday, A. J., and Hughes, J. A.: Foraminifera associated with phytodetritus deposits at a bathyal site in the northern Rockall Trough (NE Atlantic): seasonal contrasts and a comparison of stained and dead assemblages, Mar. Micropaleontol., 46, 83110,2002

Gordon, E. S., and Goñi, M. A.: Sources and distribution of terrigenous organic matter delivered by the Atchafalaya River to sediments in the northern Gulf of Mexico, Geochimica et Cosmochimica Acta, 67, 2359-2375, 2003.

Got, H., and Aloisi, J. C.: The Holocene sedimentation on the Gulf of Lions margin: a quantitative approach, Cont. Shelf Res., 10, 841-855, 1990.

Gustafsson, M., and Nordberg, K.: Living (stained) benthic foraminiferal response to primary production and hydrography in the deepest part of the Gullmar fjord, Swedish west coast, with comparison to Höglund's 1927 material, J. Foramin. Res., 31, 2-11, 2001.

Harloff, J., and Mackensen, A.: Recent benthic foraminiferal associations and ecology of the Scotia Sea and Argentine Basin, Mar. Micropaleontol., 31, 1-29, 1997.

Harmelin-Vivien, M., Loizeau, V., Mellon, C., Beker, B., Arlhac, D., Bodiguel, X., Ferraton, F., Hermand, R., Philippon, X., and Salen-Picard, C.: Comparison of $\mathrm{C}$ and $\mathrm{N}$ stable isotope ratios between surface particulate organic matter and microphytoplankton in the Gulf of Lions (NW Mediterranean), Cont. Shelf Res., 28, 1911-1919, 2008.

Hayek, L. E. C., and Buzas, M. A.: Surveying Natural Populations, edited by: Columbia University Press, New York, 563 pp., 1997.

Hermand, R., Salen-Picard, C., Alliot, E., and Degiovanni, C.: Macrofaunal density, biomass and composition of estuarine sediments and their relationship to the river plume of the Rhone River (NW Mediterranean), Estuar. Coast. Shelf S., 79, 367-376, 2008.

Hess, S., Alve, E., Rygg, B., and Telford, R. J.: Monitoring benthic community recovery in the Oslofjord: responses to capping and reoxygenation, FORAMS 2010, International Symposium on Foraminifera, Bonn, Germany, 106-107, 2010.

Hohenegger, J., Piller, W., and Baal, C.: Reasons for spatial mi- crodistributions of foraminifers in an intertidal pool (northern Adriatic Sea), Marine Ecology, 10, 43-78, 1989.

Hohenegger, J., Piller, W. E., and Baal, C.: Horizontal and vertical spatial microdistribution of foraminifers in the shallow subtidal Gulf of Trieste, northern Adriatic Sea, J. Foramin. Res., 23, 79101, 1993.

Hyams-Kaphzan, O., Almogi-Labin, A., Benjamini, C., and Herut, B.: Natural oligotrophy vs. pollution-induced eutrophy on the SE Mediterranean shallow shelf (Israel): Environmental parameters and benthic foraminifera, Mar. Pollut. Bull., 58, 1888-1902, 2009.

Jones, G. D.: A paleoecological model of late Paleocene "flyschtype" agglutinated foraminifera using the paleoslope transect approach, Viking Graben, North Sea Abhandlungen der Geologischen Bundesanstalt, 41, 143-153, 1988.

Jorissen, F. J.: The distribution of benthic foraminifera in the Adriatic Sea, Mar. Micropaleontol., 12, 21-48, 1987.

Jorissen, F. J.: Benthic foraminifera from the Adriatic Sea; Principles of phenotypic variation, Utrecht Micropaleontology Bulletin 37, 176 pp., 1988.

Jorissen, F. J., Barmawidjaja, D. M., Puskaric, S., and van der Zwaan, G. J.: Vertical distribution of benthic foraminifera in the northern Adriatic Sea: The relation with the organic flux, Mar. Micropaleontol., 19, 131-146, 1992.

Jorissen, F. J., de Stigter, H. C., and Widmark, J. G. V.: A conceptual model explaining benthic foraminiferal microhabitats, Mar. Micropaleontol., 26, 3-15, 1995.

Kaminski, M. A.: Evidence for control of abyssal agglutinated foraminiferal community structure by substrate disturbance: Results from the HEBBLE area, Mar. Geol., 66, 113-131, 1985.

Kaminski, M. A., Boersma, A., Tyszka, J., and Holbourn, A. E. L.: Response of deep-water agglutinated foraminifera to dysoxic conditions in the California Borderland basins, in: Proceedings of the Fourth International Workshop on Agglutinated Foraminifera, Kraków, Poland, edited by: Kaminski, M. A., Geroch, S., and Gasi $f$ ski, M. A., Grzybowski Foundation Special Publication no. 3, 131-140, 1995.

Kerhervé, P., Ludwig, W., Pischedda, L., Carbonne, J., and Jeanty, G.: Stable isotopic tracers $\left(\delta^{13} \mathrm{C}\right.$ and $\left.\delta^{15} \mathrm{~N}\right)$ of riverine inputs into the Gulf of Lions: results from a one-year survey, In prep.

Langezaal, A. M., Jorissen, F. J., Braun, B., Chaillou, G., Fontanier, C., Anschutz, P., and van der Zwaan, G. J.: The influence of seasonal processes on geochemical profiles and foraminiferal assemblages on the outer shelf of the Bay of Biscay, Cont. Shelf Res., 26, 1730-1755, 2006.

Lansard, B., Rabouille, C., Denis, L., and Grenz, C.: Benthic remineralization at the land-ocean interface: A case study of the Rhône River (NW Mediterranean Sea), Estuar. Coast. Shelf S., 81, 544-554, 2009.

LCHF: Action de la houle sur les sédiments, étude réalisée par le Centre National pour l'EXploitation des Océans (CNEXO), Tomes 1 et 2, 200 pp., 1976.

Lochet, F., and Leveau, M.: Transfers between a eutrophic ecosystem, the river Rhône, and an oligotrophic ecosystem, the northwestern Mediterranean Sea, Hydrobiologia, 207, 95-103, 1990.

Lohrenz, S. E., Dagg, M. J., and Whitledge, T. E.: Enhanced primary production at the plume/oceanic interface of the Mississippi River, Cont. Shelf Res., 10, 639-664, 1990.

Lohrenz, S. E., Fahnenstiel, G. L., Redalje, D. G., Lang, G. A., 
Chen, X., and Dagg, M. J.: Variations in primary production of northern Gulf of Mexico continental shelf waters linked to nutrient inputs from the Mississippi River, Mar. Ecol. Prog. Ser., 155, 45-54, 1997.

Lukina, T. G.: Foraminifera of the Laptev Sea, Protistology, 2, 105122, 2001.

Mackensen, A., Grobe, H., Kuhn, G., and Fütterer, D. K.: Benthic foraminiferal assemblages from the eastern Weddell Sea between 68 and $73^{\circ} \mathrm{S}$ : Distribution, ecology and fossilization potential, Mar. Micropaleontol., 16, 241-283, 1990.

Migniot, C., and Viguier, J.: Influence de l'extraction des granulats en mer sur l'équilibre du littoral, La Houille Blanche, 3-1980, 177-193, 1980.

Millot, C.: The Gulf of Lions' hydrodynamics, Cont. Shelf Res., 10, 885-894, 1990.

Millot, C.: Circulation in the Western Mediterranean Sea, J. Marine Syst., 20, 423-442, 1999.

Miralles, J., Radakovitch, O., and Aloisi, J.-C.: ${ }^{210} \mathrm{~Pb}$ sedimentation rates from the Northwestern Mediterranean margin, Mar. Geol., 216, 155-167, 2005.

Mojtahid, M., Jorissen, F., Lansard, B., Fontanier, C., Bombled, B., and Rabouille, C.: Spatial distribution of live benthic foraminifera in the Rhône prodelta: Faunal response to a continental-marine organic matter gradient, Mar. Micropaleontol., 70, 177-200, 2009.

Mojtahid, M., Jorissen, F., Lansard, B., and Fontanier, C.: Microhabitat selection of benthic foraminifera in sediments off the Rhône River mouth (NW Mediterranean), J. Foramin. Res., 40, 231-246, 2010.

Morvan, J., Debenay, J.-P., Jorissen, F., Redois, F., Bénéteau, E., Delplancke, M., and Amato, A.-S.: Patchiness and life cycle of intertidal foraminifera: Implication for environmental and paleoenvironmental interpretation, Mar. Micropaleontol., 61, 131154, 2006.

Murray, J. W.: Ecology and Applications of Benthic Foraminifera, edited by: Cambridge University Press, Cambridge, 426 pp., 2006.

Murray, J. W., and Bowser, S. S.: Mortality, protoplasm decay rate, and reliability of staining techniques to recognize 'living' foraminifera: a review, J. Foramin. Res., 30, 66-70, 2000.

Naudin, J. J., Cauwet, G., Chrétiennot-Dinet, M. J., Deniaux, B., Devenon, J. L., and Pauc, H.: River Discharge and Wind Influence Upon Particulate Transfer at the Land-Ocean Interaction: Case Study of the Rhône River Plume, Estuar. Coast. Shelf S., 45, 303-316, 1997.

Pastor, L., Deflandre, B., Viollier, E., Cathalot, C., Metzger, E., Rabouille, C., Escoubeyrou, K., Lloret, E., Pruski, A. M., Vétion, G., Desmalades, M., Buscail, R., and Grémare, A.: Influence of the organic matter composition on benthic oxygen demand in the Rhône River prodelta (NW Mediterranean Sea), Cont. Shelf Res., 31, 1008-1019, 2011.

Pont, D., Simonnet, J. P., and Walter, A. V.: Medium-term Changes in Suspended Sediment Delivery to the Ocean: Consequences of Catchment Heterogeneity and River Management (Rhône River, France), Estuar. Coast. Shelf S., 54, 1-18, 2002.

Rabineau, M., Berné, S., Aslanian, D., Olivet, J.-L., Joseph, P., Guillocheau, F., Bourillet, J.-F., Ledrezen, E., and Granjeon, D.: Sedimentary sequences in the Gulf of Lion: A record of 100,000 years climatic cycles, Mar. Petrol. Geol., 22, 775-804, 2005.
Rabouille, C., Denis, L., Dedieu, K., Stora, G., Lansard, B., and Grenz, C.: Oxygen demand in coastal marine sediments: comparing in situ microelectrodes and laboratory core incubations, J. Exp. Mar. Biol. Ecol., 285-286, 49-69, 2003.

Rossi, V., and Vaiani, S. C.: Benthic foraminiferal evidence of sediment supply changes and fluvial drainage reorganization in Holocene deposits of the Po Delta, Italy, Mar. Micropaleontol., 69, 106-118, 2008.

Sabatier, F., and Suanez, S.: Evolution of the Rhône delta coast since the end of the 19th century, Géomoprhologie: Relief, Processus, Environnement, 47, 283-300, 2003.

Salen-Picard, C., Darnaude, A. M., Arlhac, D., and HarmelinVivien, M. L.: Fluctuations of macrobenthic populations: a link between climate-driven river runoff and sole fishery yields in the Gulf of Lions, Oecologia, 133, 380-388, 2002.

Schmiedl, G., de Bovée, F., Buscail, R., Charrière, B., Hemleben, C., Medernach, L., and Picon, P.: Trophic control of benthic foraminiferal abundance and microhabitat in the bathyal Gulf of Lions, western Mediterranean Sea, Mar. Micropaleontol., 40, 167-188, 2000.

Scott, D. B., Tobin, R., Williamson, M., Medioli, F. S., Latimer, J. S., Boothman, W. A., Asioli, A., and Haury, V.: Pollution monitoring in two North American estuaries: Historical reconstructions using benthic foraminifera, J. Foramin. Res., 35, 65-82, 2005.

Silva, K. A., Corliss, B. H., Rathburn, A. E., and Thunell, R. C.: Seasonality of living benthic foraminifera from the San Pedro Basin, California Borderland, J. Foramin. Res., 26, 71-93, 1996.

Stouff, V., Lesourd, M., and Debenay, J.-P.: Laboratory observations on asexual reproduction (schizogony) and ontogeny of Ammonia tepida with comments on the life cycle, J. Foramin. Res., 29, 75-84, 1999.

Suanez, S.: Dynamiques sédimentaires actuelles et récentes de la frange littorale orientale du delta du Rhône, PhD Thesis, Université d'Aix Marseille I, 1997.

Swallow, J. E.: Intra-annual variability and patchiness in living assemblages of salt-marsh foraminifera from Mill Rythe Creek, Chichester Harbour, England, Journal of Micropalaeontology, 19, 9-22, 2000.

Tesi, T., Miserocchi, S., Goñi, M. A., and Langone, L.: Source, transport and fate of terrestrial organic carbon on the western Mediterranean Sea, Gulf of Lions, France, Mar. Chem., 105, 101-117, 2007.

van der Zwaan, G. J., and Jorissen, F.: Biofacial patterns in riverinduced shelf anoxia, In: Modern and Ancient Continental Shelf Anoxia. Geological Society, Special Publication, 58, 65-82, 1991.

Vázquez Riveiros, N., and Patterson, R. T.: An illustrated guide to fjord foraminifera from the Seymour-Belize inlet complex, Northern Bristish Columbia, Canada, Palaeontol. Electron., 11, 2A:45p, 2007.

Walton, W. R.: Techniques for recognition of living Foraminifera, Contributions from the Cushman Foundation for Foraminiferal Research, 3, 56-60, 1952. 